\title{
Antibiotic Residues in Animal Waste: Occurrence and Degradation in Conventional Agricultural Waste Management Practices
}

\author{
Amanda Van Epps ${ }^{1} \cdot$ Lee Blaney ${ }^{2}$ \\ Published online: 20 May 2016 \\ (C) Springer International Publishing AG 2016
}

\begin{abstract}
The presence of antibiotics in animal manure represents a significant concern with respect to the introduction of antibiotic residues to the environment and the development of antibiotic-resistant pathogens. In this review, we have (1) compiled reported detections of antibiotics in poultry litter, swine manure, and cattle manure; and (2) discussed the treatment of antibiotics during conventional agricultural waste management practices. The most reported antibiotics in animal manure were fluoroquinolones, sulfonamides, and tetracyclines, all of which the World Health Organization has listed as critically important for human health. Relatively high treatment efficiencies were observed for antibiotics in composting, anaerobic digestion, and aerobic/anaerobic lagooning. Interestingly, active management of compost piles did not demonstrate a significant increase in antibiotic degradation; however, low- and high-intensity compost systems exhibited high treatment efficiencies for most antibiotics. Anaerobic digestion was not effective for some key antibiotics, including lincosamides and select sulfonamides and fluoroquinolones. Given the potential for energy recovery during anaerobic digestion of agricultural waste, efforts to optimize antibiotic
\end{abstract}

This article is part of the Topical Collection on Water Pollution

Disclaimer This paper is the result of the authors' independent research and does not represent the views of the U.S. Environmental Protection Agency or the U.S. government.

Lee Blaney

blaney@umbc.edu

1 United States Environmental Protection Agency, 1200 Constitution Ave. NW, Washington, DC 20460, USA

2 Department of Chemical, Biochemical and Environmental Engineering, University of Maryland, Baltimore County, 1000 Hilltop Circle, ECS 314, Baltimore, MD 21250, USA degradation represent an important area for future research. Lagoons also exhibited fairly high levels of antibiotic treatment, especially for aerobic systems; however, the operational costs/complexity of these systems inhibit utilization at the fullscale. No overall trends in antibiotic treatment efficiency during these three agricultural waste management practices were observed. Finally, we posit that increased efforts to include analysis of antibiotic residues in animal manure in national surveillance programs will provide important information to address concerns over the continued use of antimicrobials in animal feeding operations.

Keywords Antibiotics · Agricultural waste $\cdot$ Animalmanure Composting $\cdot$ Anaerobic digestion $\cdot$ Antimicrobial resistance

\section{Introduction}

The discovery of antibiotics in the 1940s [1-4] spurred a new era of human health. Extension of the benefits and advantages of antibiotics to food animals occurred almost immediately. By 1951, the antibiotic additive market for manufactured animal feeds was \$17.5 million [5]. Ten years later, \$24 million of antibiotics were used for disease control, and an additional $\$ 19$ million of antibiotics were employed for nutrition and feed efficiency (i.e., growth promotion) [5]. The animal antibiotics and antimicrobials market reached \$3.3 billion in 2013 and is expected to exceed $\$ 4.1$ billion by 2018 [6]. The extreme growth of this industry stems from two major factors: (1) increased animal production over the past half century and (2) concentration of animal feeding operations. For example, the total US availability (millions of tons) of beef, pork, and chicken from 1951 to 2013 was 3.18-8.47, 3.48-6.88, and 1.16-9.13, respectively [7]; for reference, the US population doubled over the same period. The transition from traditional 
farms to concentrated animal feeding operations (CAFOs), which produce hundreds of thousands to millions of animals per farm each year, has necessitated increased antibiotic use to prevent the spread of disease among animals raised in close confines.

Several concerns arise from the use of antibiotics in animal feeding operations: incorporation of antibiotics into animal products, development of single- and multidrug resistance, introduction of resistant bacteria to the environment, and discharge of antibiotic residues to environmental systems. The recent bans on organoarsenical use in the USA were instigated by detection of arsenic in poultry meat $[8,9]$. Development of new microbiological tools and high-throughput sequencing has spurred a significant body of literature on the presence of antibiotic-resistant organisms and antimicrobial resistance genes in animal manure [10-12]. Land application of agricultural waste containing antibiotic residues is an emerging concern, since this practice facilitates the spread of antibiotic resistance [13-15]. For example, one study found that Enterococcus spp. sampled from 82 farms on the poultryintensive eastern shore of Maryland were resistant to lincosamides, macrolides, and tetracyclines [16]. Moreover, a number of studies have detected antibiotics in animal waste [17-22]; however, synthesis of reported antibiotic concentrations in animal waste is needed to design and test treatment technologies that ensure degradation of antimicrobials in animal waste before use as fertilizers and soil amendments. To date, the most commonly employed agricultural treatment systems involve biological processes, such as composting, anaerobic digestion, and anaerobic/aerobic lagooning [23].

The main objectives of this review are as follows:

1. Describe antibiotics employed in production of the three leading food animals (i.e., poultry, swine, and cattle) and compile detections of these antibiotics in manure

2. Identify degradation of antibiotics during composting, anaerobic digestion, and anaerobic/aerobic lagooning of agricultural waste

\section{Antibiotic Presence in Agricultural Waste}

\section{Antibiotic Use in Food Animals}

As indicated above, antibiotic use in animal feeding and production operations began in the 1940s. Antibiotics are primarily added to animal feed for three purposes: to treat disease (therapeutic levels), to prevent disease (subtherapeutic levels), and to promote animal growth (subtherapeutic levels). In the USA, "subtherapeutic" use of antibiotics is defined as concentrations less than $2 \mathrm{~g} / \mathrm{t}$ feed over a time course longer than 2 weeks [24]. In half of the world's countries, primary antibiotic use stems not from therapeutic use but from prophylactic needs (i.e., mitigating infection and spread of disease) and growth promotion (i.e., growing bigger animals faster) [25]. The benefits of feeding subtherapeutic levels of antibiotics to animals have been known since the mid-1940s. A 1946 report from Moore et al. [26] identified increased chick growth with sulfasuxidine (sulfonamide), streptothricin (streptothricin), and streptomycin (aminoglycoside) treatment; a marked reduction in coliform bacteria was also observed in the cecal contents. Gaskins et al. [27] summarized four mechanisms responsible for the effects of growth-promoting antibiotics: inhibition of subclinical infections, reduction of growth-depressing microbial metabolites, reduction of microbial use of nutrients, and enhanced uptake and use of nutrients. While the use of antimicrobial growth promoters has consistently increased since the 1950 s, a growing number of developed countries have restricted the use of antimicrobials for growth promotion due to antimicrobial resistance concerns [28].

Antibiotic doses in animal feed vary by compound, animal, and country. Bolan et al. [29] assembled a list of antimicrobial doses for poultry production, which included maximal doses of $77 \mathrm{mg} / \mathrm{kg}$ amprolium (coccidiostat), $26 \mathrm{mg} / \mathrm{kg}$ chlortetracycline (tetracycline), $152 \mathrm{mg} / \mathrm{kg}$ nicarbazin (coccidiostat), $29 \mathrm{mg} / \mathrm{kg}$ oxytetracycline (tetracycline), and $25 \mathrm{mg} / \mathrm{kg}$ penicillin (beta-lactam). McEwen and Fedorka-Cray [30] reported that growth promoters are typically administered at 2.5$125 \mathrm{mg} / \mathrm{kg}$. However, measured concentrations of antibiotics in manure regularly exceed these levels, indicating the widespread misuse of antimicrobial feed additives. A US Department of Agriculture (USDA) study from 1999 found that $83 \%$ of cattle feedlots administered subtherapeutic levels of at least one antibiotic to cattle [24]. Using data from 710 farms and 3328 animal feeds, Dewey et al. [31] found that 699 feeds used antimicrobial additives incorrectly, that is at higher than recommended concentrations or on the incorrect class of pig. The dominant antimicrobial additives in that study were tetracyclines (1898 feeds; $79 \%$ labeled use), followed by penicillins (468 feeds; $88 \%$ labeled use) and carbadox, an anti-dysentery drug used in swine (410 feeds; $67 \%$ labeled use) [31]. Broilers are often grown in flocks as large as 100, 000 birds, precluding single-bird-based treatment. For that reason, antimicrobials are administered through the water supply [30]. This process may result in differential dosing across the flock and result in elevated antibiotic levels in poultry litter.

According to the US Food and Drug Administration (FDA), 18 classes of antimicrobials are approved for use in food-producing animals [32]. These classes include the following: aminocoumarins, aminoglycosides, amphenicols, cephalosporins, diaminopyrimidines, fluoroquinolones, glycolipids, ionophores, lincosamides, macrolides, penicillins, pleuromutilins, polymyxins, polypeptides, quinoxalines, 
streptogramins, sulfonamides, and tetracyclines. In general, these antimicrobials are introduced to animals through feed or water; however, a small fraction of antimicrobials are injected or administered by intramammary, oral, or topical means. Chee-Sanford et al. [33] assembled a list of antibiotic classes used in production of poultry, swine, and cattle using available data from the US Government Accountability Office (GAO) and USDA. These animal-class pairs are summarized below:

- Poultry: aminocoumarins, aminocyclitols, aminoglycosides, beta-lactams, fluoroquinolones, glycolipids, ionophores, lincosamides, macrolides, polypeptides, quinolones, streptogramins, sulfonamides, tetracyclines

- Swine: aminocyclitols, aminoglycosides, beta-lactams, carbadox, glycolipids, lincosamides, macrolides, polypeptides, streptogramins, sulfonamides, tetracyclines

- Cattle: aminoglycosides, beta-lactams, chloramphenicol, fluoroquinolones, glycolipids, ionophores, macrolides, quinolones, streptogramins, sulfonamides, tetracyclines

Consumption of antimicrobials is not equal between classes. The Animal Health Institute [34] conducted a survey of antibiotic use in animal production. Findings from that survey indicated that ionophores/arsenicals (40\% of total use) and tetracyclines ( $37 \%$ ) were the most consumed classes, followed by penicillins $(9.4 \%)$, sulfonamides $(3.1 \%)$, aminoglycosides $(1.3 \%)$, and fluoroquinolones $(0.002 \%)$. Current use is likely to deviate from these survey results as a result of the 2013 banning of organoarsenicals, including roxarsone, carbarsone, and arsanilic acid, in the USA [35]; nitarsone was banned in 2015 [36]. Recent bans on other antimicrobial growth promoters may also be shifting global trends.

Like humans, animals do not fully metabolize antibiotics. Kumar et al. [37] assembled a list of excretion factors for various antibiotic classes, demonstrating that $75-80 \%$ of tetracyclines, $60 \%$ of lincosamides, and $50-90 \%$ of macrolides are excreted unchanged. These levels are fairly similar to urinary excretion factors in humans for tetracyclines (tetracycline, $58 \pm 8 \%$ ) but higher than those for macrolides (erythromycin, $12 \pm 7 \%$ ) and lincosamides (lincomycin, 5-15\%) [38]. Due to high consumption and incomplete metabolism, agricultural waste is expected to contain high levels of antibiotics; this hypothesis has been confirmed by numerous studies for a variety of animals [17-22]. The following subsections discuss the detection of antibiotics in poultry ("Poultry Litter"), swine ("Swine Manure"), and beef cattle ("Cattle Manure") manure.

\section{Poultry Litter}

Antibiotics have been widely detected in poultry litter. Detected concentrations of fluoroquinolones, sulfonamides, and tetracyclines varied over several orders of magnitude, as observed in Fig. 1. In fact, our assembled list of reported concentrations includes 29 different antibiotics. The highest detected antibiotics in poultry litter were fluoroquinolones, and enrofloxacin, in particular [39]. A list of antibiotics from the three most represented classes detected in poultry litter is as follows:

- Fluoroquinolones: ciprofloxacin, danofloxacin, difloxacin, enrofloxacin, fleroxacin, lomefloxacin, norfloxacin

- Sulfonamides: sulfachloropyradazine, sulfadiazine, sulfadimidine, sulfaguanidine, sulfamerazine, sulfamethoxazole, sulfamonomethoxine, sulfanilamide

- Tetracyclines: chlortetracycline, doxycycline, methacycline, oxytetracycline, tetracycline

Fluoroquinolones The highest fluoroquinolone concentrations were detected in poultry litter from China. Detected concentrations varied over six orders of magnitude, indicating that different practices between farms and countries significantly impact antibiotic residues in manure. For example, the maximum enrofloxacin concentrations in poultry litter from China, Egypt, and Austria were 1421, 31, and $8 \mathrm{mg} / \mathrm{kg}$, respectively $[18,39,40]$. Regardless, detection of enrofloxacin was consistent across these studies, with enrofloxacin being detected in 35,30 , and $25-38 \%$ of litter from China, Egypt, and Austria, respectively. Ciprofloxacin, which is a known metabolite of enrofloxacin [60-63], was also detected in the Chinese and Egyptian studies, with maximum concentrations of 46 and

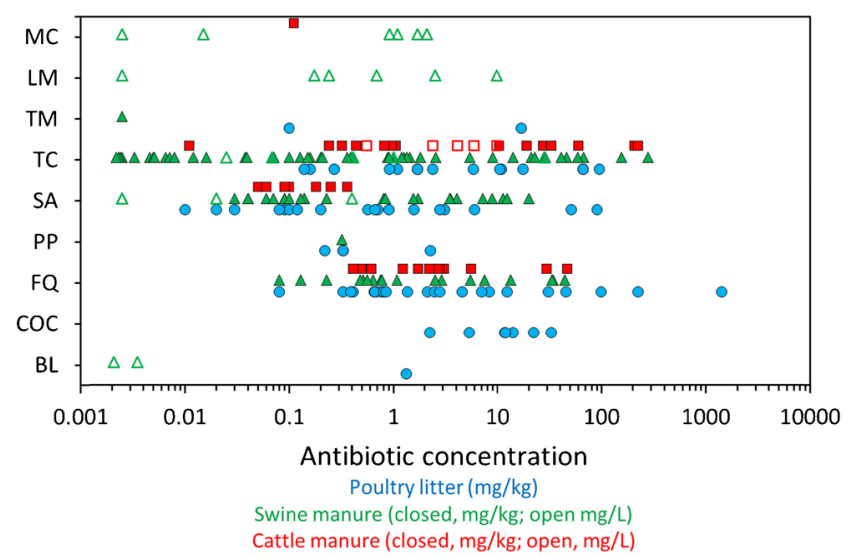

Fig. 1 Antibiotic concentrations detected in poultry, swine, and beef cattle manure. Data was aggregated from available reports $[13,16,18$, 21, 39-59]. Antibiotic class codes on the $y$-axis are as follows: $M C$ macrolide, $L M$ lincosamide, $T M$ trimethoprim, $T C$ tetracycline, $S A$ sulfonamide, $P P$ polypeptide, $F Q$ fluoroquinolone, $C O C$ coccidiostat, $B L$ beta-lactam. For clarity, only the minimum and maximum antibiotic concentrations from individual studies were included here. This list is not exhaustive but is meant to convey the relative antibiotic detection and concentration ranges in animal manures 
$2 \mathrm{mg} / \mathrm{kg}$, respectively $[18,39]$. These findings are important since ciprofloxacin is a human-use antibiotic. In fact, of the seven fluoroquinolones detected in poultry litter, only three (i.e., danofloxacin, difloxacin, and enrofloxacin) are classified for veterinary use. The widespread utilization of human-use antibiotics in animal feeding operations may contribute to increased rates of resistance development in human pathogens. This area requires additional research to safeguard the efficacy of human-use medicine.

Sulfonamides The reporting of sulfonamides in poultry litter is more limited than fluoroquinolones. This scenario may stem from low use of sulfonamides in poultry feed additives or from a dearth of studies that have investigated sulfonamide residues in poultry litter. Overall, sulfonamide consumption in animal feeds is higher than fluoroquinolones [34]; however, fluoroquinolones are more persistent in the environment. Discovery of sulfonamides occurred rapidly in the 1940s and 1950s, and widespread use in the decades since then has resulted in high levels of resistance [64]. For that reason, a decreasing dependence on sulfonamide use in food animals seems likely. The low detection frequencies (e.g., $5.6 \%$ for sulfadimidine; $7.4 \%$ for sulfamethoxazole) observed for sulfonamide antibiotics reinforce the idea that antibiotic use is shifting away from sulfonamides and to other classes. In any case, Zhao et al. [39] and Martinez-Carballo et al. [40] detected sulfonamide concentrations as high as $6 \mathrm{mg} / \mathrm{kg}$ sulfadimidine and $51 \mathrm{mg} / \mathrm{kg}$ sulfadiazine in chicken litter. Trimethoprim, which is usually co-dosed with sulfamethoxazole, has also been detected in poultry litter [40].

Tetracyclines Tetracycline residues were reported in poultry litter from Austria, China, Egypt, and the USA. The median detection frequency of tetracycline antibiotics $(\sim 28 \%)$ was similar to fluoroquinolones $(\sim 28 \%)$ and higher than sulfonamides ( $7 \%$ ). Given the AHI consumption trends [34] identified above for tetracyclines (37\% consumption) and fluoroquinolones ( $0.002 \%$ consumption), similar detection rates for tetracyclines and fluoroquinolones in poultry litter are surprising. Nevertheless, some studies have shown high detection frequency for tetracyclines. For example, Furtula et al. [13] reported chlortetracycline concentrations as high as $66 \mathrm{mg} / \mathrm{kg}$ in US poultry litter samples with a detection frequency of $60 \%$. Tetracycline resistance is common; however, tetracyclines are still widely used in human medicine and listed as critically important [65]. For that reason, the extensive detection of tetracycline residues in animal waste is a public health concern.

Beta-lactams and Polypeptides Few reports [13] were available on beta-lactam presence in poultry litter; however, penicillins and other beta-lactams are readily metabolized and are, therefore, not expected to be widely present in poultry litter. In addition, these molecules are quickly degraded in environmental matrices, decreasing long-term persistence concerns. Polypeptides are similar in this respect. Two polypeptides, bacitracin and virginiamycin, were reported at concentrations of $0.22-2.3 \mathrm{mg} / \mathrm{kg}$ in US poultry litter [13]. The relatively low concentrations of these antibiotic classes in poultry litter suggest that the use of fluoroquinolones, sulfonamides, and tetracyclines may be of greater concern; however, increased surveillance of less-consumed antibiotics will provide much needed information to verify this postulation.

Coccidiostats This antimicrobial class is used in animal production to prevent protozoan infections [66]. A number of coccidiostats, including monensin, narasin, nicarbazin, and salinomycin, were detected in poultry litter. In general, the magnitude of detected concentrations of coccidiostats in poultry litter (i.e., $2.3-33 \mathrm{mg} / \mathrm{kg}$ ) is similar to that of fluoroquinolones, sulfonamides, and tetracyclines. Consider that monensin, narasin, nicarbazin, and salinomycin were detected in US poultry litter at concentrations as high as 11.8, $32.96,22.4$, and $14.1 \mathrm{mg} / \mathrm{kg}$ [13]. However, the detection frequency of coccidiostats tended to be less than $20 \%$, whereas $20-40 \%$ was observed for fluoroquinolones, sulfonamides, and tetracyclines. Because coccidiostats are not used in human medicine, the development of resistance may be less relevant from a public health standpoint when compared to fluoroquinolones, sulfonamides, tetracyclines, beta-lactams, and polypeptides, among others. However, the influence of coccidiostats on development of multidrug resistance is an important knowledge gap given the high use in animal feed.

Organoarsenicals One important class of veterinary antibiotics missing from Fig. 1 is the organoarsenicals. As indicated above, these chemicals are banned in the USA and European Union due to concerns arising from not only arsenic incorporation into meat products $[8,9]$ but also arsenic presence in the resulting manure. Organoarsenicals are, however, still used in other parts of the world [67]. Degradation of this unique class of antimicrobials has been investigated using a variety of techniques: biological processes [68, 69], UV irradiation/ advanced oxidation [70], and adsorption [71, 72]. Due to the incorporation of arsenic moieties in organoarsenicals, transformation-based processes (i.e., oxidation and metabolism, among others) do not represent effective treatment options and phase-change (i.e., sorption, ion exchange) processes are necessary. Given the phase-out of these chemicals in the USA and European Union, they were not included in this discussion; however, Mangalgiri et al. [67] provided a comprehensive review of the use of these chemicals in poultry applications.

The widespread detection of antimicrobials in poultry litter is important in the domestic and global markets. In the USA, poultry is the number one meat product. Beef consumption 
has been decreasing since the mid-1970s, whereas poultry consumption has increased consistently since the 1950s. The per capita availability of poultry exceeded pork in 1996 and beef in 2010 [7]. In 2013, the per capita availability of poultry was $57.7 \mathrm{lb}$, compared to $53.6 \mathrm{lb}$ beef and $43.4 \mathrm{lb}$ pork [7]. On the global market, broiler production rose by $6.6 \%$ between 2011 and 2014 [73]. Unlike swine and cattle manure, poultry litter is a dry waste material; therefore, antibiotic residues may be more persistent in environmental systems. For this reason, the fate of diverse antimicrobial classes in conventional and advanced treatment systems is a critical question.

\section{Swine Manure}

The concentrations of antibiotics reported in swine manure are presented in Fig. 1. In general, the antibiotic classes and distribution of detected concentrations in swine manure align fairly well with those in poultry litter. Like poultry litter, the fluoroquinolone, sulfonamide, and tetracycline classes have been detected most widely. A number of human- and veterinary-use fluoroquinolone antibiotics, including ciprofloxacin, danofloxacin, difloxacin, enrofloxacin, fleroxacin, lomefloxacin, and norfloxacin, have been detected in swine manure and lagoons at concentrations as high as $44 \mathrm{mg} / \mathrm{kg}$ $[39,40]$. Similarly, 11 sulfonamides have been detected in swine manure from Austria, China, Germany, Switzerland, and the USA [16, 39-42]. Tetracycline antibiotics, and key metabolic products, have been widely reported in swine manure with detection frequencies as high as $73 \%$ in Austria [40]. The concentration distribution for all three classes mostly ranges between 0.01 and $100 \mathrm{mg} / \mathrm{kg}$ (or $\mathrm{mg} / \mathrm{L}$ ).

Relatively few reports documented the presence of other antimicrobial classes in swine manure. Macrolides (i.e., erythromycin and tylosin) have been detected over a wide concentration range, namely 0.001 to $10 \mathrm{mg} / \mathrm{L}[16,43-45,74,75]$. All of these detections came from US swine manure. Penicillin $G$ was also detected at microgram per liter levels in US swine lagoons [16]. While sulfamethoxazole and trimethoprim demonstrated reasonably similar concentration ranges in poultry litter, reported concentrations for trimetho$\operatorname{prim}(2.5 \mu \mathrm{g} / \mathrm{L})$ in swine lagoons were lower than sulfamethoxazole $(400 \mu \mathrm{g} / \mathrm{L})$ [16]. Two lincosamides, lincomycin and spectinomycin, were identified in swine manure from US and Canadian farms [16, 46, 76]. Kuchta and Cessna also demonstrated that lincomycin and spectinomycin are persistent in swine manure lagoons, increasing exposure of native microbial populations to high concentrations of lincosamides. For this reason, increased surveillance of antibiotic residues from these lesser consumed antimicrobial classes represents an important knowledge gap, especially with respect to the development of antimicrobial resistance.

Antimicrobial loads in swine manure vary from operation to operation. For example, Qiao et al. [21] measured five tetracycline antibiotics, and several metabolites, in swine manure from three Chinese farms. One manure demonstrated a total mass concentration of tetracyclines of $117 \mu \mathrm{g} / \mathrm{kg}$ (dry weight), whereas another exhibited over $15,200 \mu \mathrm{g} / \mathrm{kg}$ [21]. The two farms with elevated tetracycline content in swine manure showed predominant use of either chlortetracycline or oxytetracycline. Other reports show more consistent antibiotic levels. For example, Angenent et al. [43], Stone et al. [47], and Loftin et al. [44] all identified maximum tylosin concentrations of $1.1-2.1 \mathrm{mg} / \mathrm{L}$ in swine manure from US farms.

The diversity of antimicrobials detected in US swine manure includes the following: penicillin G, lincomycin, erythromycin, tylosin, bacitracin, sulfadimethoxine, sulfamethazine, sulfamethoxazole, chlortetracycline, oxytetracycline, and trimethoprim [16, 43-45, 47-49]. This diversity is concerning as the complex mixture of antimicrobials in swine manure/lagoons may more readily lead to the development of multidrug-resistant pathogens. Compounding this threat is the increased demand for pork products in the USA. In the 19902013 period, total pork production has consistently increased from 11.6 billion $\mathrm{lb}$ to 13.8 billion $\mathrm{lb}$ [7]. As swine production continues to increase, effective treatment of antibiotic residuals is an important need.

\section{Cattle Manure}

Less information is available for antibiotic concentrations in manure from beef cattle. Our analysis demonstrated that the number of antimicrobial classes used in beef cattle was more restricted compared to poultry and swine. As expected, fluoroquinolones, sulfonamides, and tetracyclines were all detected; however, other antibiotic classes have not been widely reported. De Liguoro et al. [50] detected $0.11 \mathrm{mg} / \mathrm{kg}$ of tylosin (macrolide) in US beef cattle manure. The corresponding concentrations of antibiotics identified in cattle manure are presented in Fig. 1. In general, the concentration distributions for fluoroquinolones and tetracyclines in cattle manure were consistent with those observed in poultry litter and swine manure (i.e., 0.1 to $100 \mathrm{mg} / \mathrm{kg}$ ), but sulfonamide levels were lower.

In a comprehensive study, Zhao et al. [39] measured seven fluoroquinolones, eight sulfonamides, and four tetracyclines in manure from large-scale animal feedlots in China. With the exception of three sulfonamides, each of the 16 other investigated antibiotics were detected in cattle manure. Chlortetracycline and enrofloxacin exhibited detection frequencies of 82.1 and $64.3 \%$, respectively [39]. In general, fluoroquinolones and tetracyclines were detected more frequently and at higher concentrations than sulfonamides. The maximum detected concentrations were as follows: oxytetracycline, $59.59 \mathrm{mg} / \mathrm{kg}$; enrofloxacin, $46.70 \mathrm{mg} / \mathrm{kg}$; ciprofloxacin, $29.59 \mathrm{mg} / \mathrm{kg}$; and chlortetracycline, $27.59 \mathrm{mg} / \mathrm{kg}$ [39]. An important aspect of these findings is the similarity of antimicrobial detections in poultry litter, swine manure, and cattle 
manure. For that reason, it may be useful to consider these four molecules as priority pollutants that can be used as chemical markers for the fate and transport of antimicrobials in agricultural settings or in agricultural waste management practices.

Other studies primarily reported tetracycline presence in cattle manure. Chlortetracycline was identified in cattle manure from China, Germany, and Turkey at concentrations ranging from 0.011 to $208 \mathrm{mg} / \mathrm{kg}$ [39, 51, 52, 77, 78]. The other dominant tetracycline used in cattle production was oxytetracycline. Identified oxytetracycline levels in cattle manure were 0.32 to $225 \mathrm{mg} / \mathrm{kg}$ [39, 50, 53-55]. Arikan and coworkers [51, 54, 78] detected metabolic products from oxytetracycline and chlortetracycline in cattle manure; however, these levels were generally lower than the corresponding parent antimicrobials. Identification of other metabolites from the fluoroquinolone and sulfonamide classes, among others, in animal manure is a critical knowledge gap. This need is especially important when metabolic products retain antimicrobial activity and the ability to instigate development of antimicrobial resistance.

In the USA, per capita beef consumption has dropped from $64.5 \mathrm{lb} /$ person in 2000 to $53.6 \mathrm{lb} /$ person in 2013 [7]. However, global beef (and veal) consumption increased about $1 \%$ between 2011 and 2015 [73]. This trend, along with the increased use of antibiotics in animal production, is expected to lead to increased antibiotic loading to sensitive watersheds. That scenario may result in the development and spread of antimicrobial resistance. In fact, a number of efforts have already demonstrated the impact of CAFOs on discharge of antimicrobial resistance genes [79]. Furthermore, this situation may be enhanced in developing countries with less stringent environmental regulations. Consider that Brazil, China, and India produced approximately $35 \%$ of global beef/veal in 2015 [73]; in addition, these countries accounted for about $38 \%$ of beef/veal exports. An important question for the continued development and integration of global meat markets involves the ability of animal feeding operations to minimize antibiotic residues and resistance.

\section{Identification of Priority Antibiotics}

The USDA Economic Research Service has reported the per capita availability of beef, pork, and chicken since 1909 [7]. Using those data with the annual US population and average meat production per animal (i.e., $5.9 \mathrm{lb} /$ chicken, $283 \mathrm{lb} / \mathrm{pig}$, and $1300 \mathrm{lb} / \mathrm{cow}$ [80]), we computed the equivalent animal production. Typical lifetime manure production values for poultry, swine, and beef cattle are 11, 1287, and 20,300 lb/animal, respectively [80]. With this information, the total US manure production was calculated. From the literature used to generate Fig. 1, the median reported fluoroquinolone, sulfonamide, and tetracycline concentrations for each animal were determined: [fluoroquinolone] = poultry, $2.13 \mathrm{mg} / \mathrm{kg}$; swine, $0.93 \mathrm{mg} / \mathrm{kg}$; cattle, $2.43 \mathrm{mg} / \mathrm{kg}$; [sulfonamide] = poultry, $0.62 \mathrm{mg} / \mathrm{kg}$; swine, $0.19 \mathrm{mg} / \mathrm{kg}$; cattle, $0.095 \mathrm{mg} / \mathrm{kg}$; [tetracycline] = poultry, $2.39 \mathrm{mg} / \mathrm{kg}$; swine, $0.36 \mathrm{mg} / \mathrm{kg}$; cattle, $2.40 \mathrm{mg} / \mathrm{kg}$. The median reported frequency of detection for each class-animal pair was also collected. The total manure production was multiplied by the median antibiotic concentration and median detection frequency to yield the total estimated antibiotic loads in poultry, swine, and cattle manure (Fig. 2).

From Fig. 2, it is clear that the estimated antibiotic load in animal manure has increased since 1990. Note that antibiotic use was not deconvoluted with time; therefore, the trends in total estimated antibiotic loads directly follow animal production trends. Nevertheless, it is interesting to note that FDA data has shown consistent increases in antimicrobial use in animal production. For example, between 2009 and 2013, total antimicrobial use increased $17 \%$, from 12.6 million $\mathrm{kg}$ to 14.8 million $\mathrm{kg}$ [32]. For that reason, the estimated antibiotic loads shown in Fig. 2 may be conservative.

Many of the antibiotics identified above have been identified as "critically important antimicrobials" by WHO [81]. This classification involves meeting two criteria:

Criterion 1 An antimicrobial agent, which is the sole (or one of limited) available therapy, to treat serious human disease

Criterion 2 An antimicrobial agent that is used to treat diseases caused by either: (1) organisms that may be transmitted to humans from nonhuman sources, or (2) human diseases caused by organisms that may acquire resistance genes from nonhuman sources

Those antibiotics that meet one criterion are deemed "highly important," whereas those compounds that meet neither requirement are "important" [81]. Table 1 provides a summary of antibiotics detected in animal manure, including the WHO classification and maximum detections in poultry litter, swine manure, and cattle manure. While the use of critically important antibiotics in animal production may be cause for concern regarding food quality, the presence of critically important antibiotics in animal manure may represent an even larger threat due to potential introduction of antibiotic residues, antibioticresistant bacteria, and antimicrobial resistance genes to environmental systems. For this reason, effective treatment of antibiotics in agricultural waste treatment systems is paramount.

\section{Degradation of Antibiotics in Agricultural Waste Management}

In many cases, animal manure is directly applied to land as a fertilizer or soil amendment. However, in other scenarios, treatment processes are employed prior to land application of 

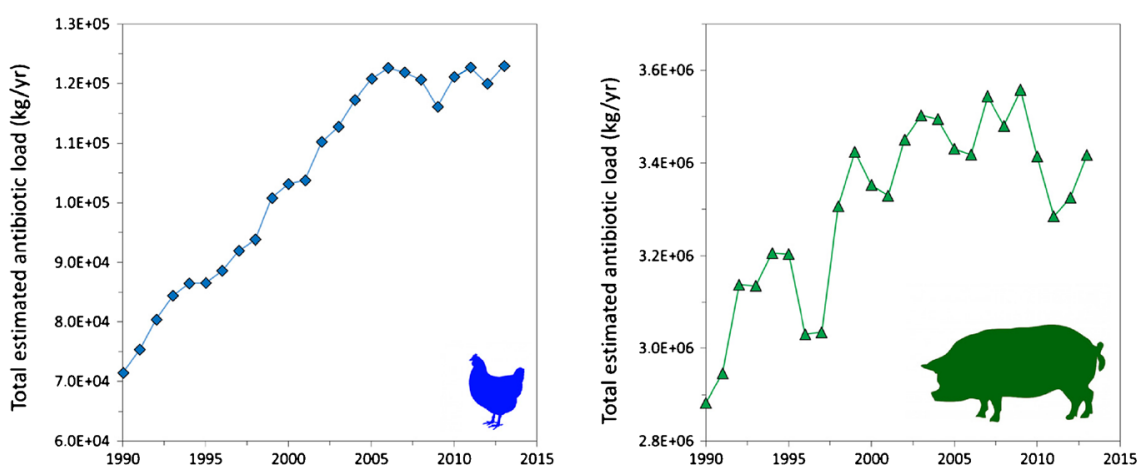

Fig. 2 Total estimated antibiotic load from US poultry, swine, and beef cattle production. The total pounds of meat available from poultry, swine, and beef cattle were collected from the USDA Economic Research Service [7]. These amounts were divided by the average weight of broilers $(5.9 \mathrm{lb}), \operatorname{hogs}(283 \mathrm{lb})$, and beef cattle $(1300 \mathrm{lb})$ at slaughter to determine the number of animals produced [80]. Average lifetime manure production was estimated at 11,1287 , and $20,300 \mathrm{lb} /$ animal for poultry,

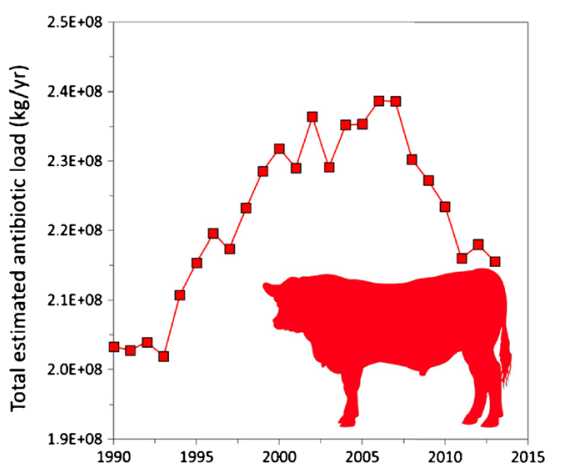

swine, and beef cattle, respectively [80]. The total manure production for each animal was multiplied by the median concentrations and frequencies of detection for fluoroquinolone, sulfonamide, and tetracycline antibiotics (from data used to generate Fig. 1). Other antibiotics are not included in this analysis. Differences in antibiotic feeding rates are not included for the 1990-2013 period agricultural waste. Manure treatment has a variety of objectives, including reducing the volume of waste and converting it to usable products, such as a nutrient-rich fertilizer or biogas [82, 83]. Treatment options range from relatively straightforward practices, such as those that occur in manure piling, lowintensity composting, or storage in anaerobic lagoons, to treatment processes that require greater management (e.g., highintensity composting, anaerobic digestion, and aerobic lagooning).

The USDA's Agricultural Waste Management Field Handbook [23] reviews typical waste management systems for many animal handling facilities, including dairy, beef, swine, and poultry operations. The preferred treatment option largely depends on the solids content of the manure. In many cases, solid-liquid separation is performed, and the two waste streams are treated separately. Separated solids are typically composted. Poultry litter, which is a relatively dry waste, can be directly composted. The liquid fraction of manure streams is typically treated in anaerobic or aerobic lagoons. In some cases, the complete manure (i.e., no solid-liquid separation) or the separated liquid component are treated by anaerobic digestion. These USDA descriptions are generally consistent with the findings from a survey of 100 farms in northeast Spain, which found that composting was the most commonly employed treatment practice, and that while only two farms currently employed anaerobic digestion, new facilities were planned and under construction [84]. A comprehensive discussion of the fate of antibiotics in the three most common types of manure treatment, namely composting, anaerobic digestion, and lagooning, follows in the below sections.

\section{Composting}

Composting covers a range of manure management activities that take advantage of microbial processes to aerobically degrade organic material, stabilize the waste, and reduce odor and pathogens. In some cases, the manure pile is mixed with organic materials, such as sawdust or dried leaves, that help with balancing nutrient conditions and enhancing aeration; furthermore, the compost may be turned to increase oxygen availability within the pile [23]. In all cases, microbial processing during composting raises the temperature of the manure pile.

A number of studies have found that the presence of various antibiotics (i.e., chlortetracycline, oxytetracycline, and tetracycline) does not significantly affect the composting process $[51,53,85,86]$. These findings have been confirmed using the temperature profile, the normalized mass of carbon dioxide produced, the volatile solids content, $\mathrm{pH}$ changes, moisture content, and the carbon to nitrogen ratio in the compost pile.

As shown in Table 2, a majority of studies have found antibiotic treatment efficiencies of $\geq 90 \%$. Those studies have investigated the following antimicrobials: chlortetracycline [21, 51, $56,77,85,87,89-91]$, doxycycline [21], iso-chlortetracycline (a metabolite of chlortetracycline) [51, 77], methacycline [21], monensin [91], oxytetracycline [21, 53, 77, 85, 91], salinomycin [88], sulfadiazine [89], sulfamethazine [90]; tetracycline [21, 85, 91], and tylosin [90, 91]. Lower treatment efficiencies have been reported for chlortetracycline [56], ciprofloxacin [89], monensin [87], sulfamethazine [87], and tylosin [87] in select studies, indicating a dependence on composting technique and management. Furthermore, a variety of manure types have been investigated, including swine [21, 56, 85, 89, 90], poultry [56, 85, 87, 88], cattle [51, 53, 77, 91], and horse [91]. Antimicrobial treatment efficiencies were highest during the early, high-temperature thermophilic phase of composting [53, 56, 77, 88, 89].

Arikan et al. [51] found negligible chlortetracycline and iso-chlortetracycline residuals in composted mixtures and sterilized mixtures that were incubated at $55{ }^{\circ} \mathrm{C}$. However, lower treatment efficiencies were observed in mixtures 
Table 1 Overview of antibiotic classes used in animal production

\begin{tabular}{|c|c|c|c|c|c|c|c|}
\hline Class & Antibiotic & Primary use & WHO classification & $\begin{array}{l}\text { Max. conc. } \\
(\mathrm{mg} / \mathrm{kg}) \text { in } \\
\text { poultry litter }\end{array}$ & $\begin{array}{l}\text { Max. conc. } \\
(\mathrm{mg} / \mathrm{kg} \text { or } \mathrm{mg} / \mathrm{L}) \\
\text { in swine manure }\end{array}$ & $\begin{array}{l}\text { Max. conc. } \\
\text { ( } \mathrm{mg} / \mathrm{kg} \text { or } \mathrm{mg} / \mathrm{L}) \\
\text { in cattle manure }\end{array}$ & References \\
\hline Beta-lactam & Penicillin & Human & Critically important & 1.33 & 0.0035 & & {$[13,16]$} \\
\hline Coccidiostat & Monensin & Veterinary & $\mathrm{n} / \mathrm{a}$ & 11.8 & & & {$[13]$} \\
\hline Coccidiostat & Narasin & Veterinary & $\mathrm{n} / \mathrm{a}$ & 32.96 & & & {$[13]$} \\
\hline Coccidiostat & Nicarbazin & Veterinary & $\mathrm{n} / \mathrm{a}$ & 22.4 & & & {$[13]$} \\
\hline Coccidiostat & Salinomycin & Veterinary & $\mathrm{n} / \mathrm{a}$ & 14.1 & & & {$[13]$} \\
\hline Fluoroquinolone & Ciprofloxacin & Human & Critically important & 45.59 & 33.98 & 29.59 & [39] \\
\hline Fluoroquinolone & Danofloxacin & Veterinary & Critically important & 2.48 & 2.92 & 3.06 & [39] \\
\hline Fluoroquinolone & Difloxacin & Veterinary & Critically important & 12.38 & 2.51 & 2.63 & [39] \\
\hline Fluoroquinolone & Enrofloxacin & Veterinary & Critically important & 1420.76 & 33.26 & 46.7 & [39] \\
\hline Fluoroquinolone & Fleroxacin & Human & Critically important & 99.43 & 7.46 & 2.22 & [39] \\
\hline Fluoroquinolone & Lomefloxacin & Human & Critically important & 7.03 & 44.16 & 5.53 & [39] \\
\hline Fluoroquinolone & Norfloxacin & Human & Critically important & 225.45 & 5.5 & 2.76 & [39] \\
\hline Lincosamide & Lincomycin & Human & Highly important & & 9.78 & & {$[46]$} \\
\hline Lincosamide & Spectinomycin & Human & Important $\mathrm{t}^{\mathrm{a}}$ & & 0.686 & & {$[46]$} \\
\hline Macrolide & Erythromycin & Human & Critically important & & 0.0025 & & {$[16]$} \\
\hline Macrolide & Tylosin & Veterinary & Critically important & & 2.1 & 0.11 & {$[43,50]$} \\
\hline Polypeptide & Bacitracin & Human & Important & 2.27 & 0.32 & & {$[13,48]$} \\
\hline Polypeptide & Virginiamycin & Veterinary & Highly important & 0.33 & & & {$[13]$} \\
\hline Sulfonamide & Sulfachloropyridazine & Human & Highly important ${ }^{\mathrm{b}, \mathrm{c}}$ & 0.71 & 3.51 & 0.36 & [39] \\
\hline Sulfonamide & Sulfadiazine & Human & Highly important $\mathrm{c}^{\mathrm{c}}$ & 91 & 11.3 & & {$[40,41]$} \\
\hline Sulfonamide & Sulfadimethoxine & Human & Highly important ${ }^{\mathrm{c}}$ & & 0.0025 & & {$[16]$} \\
\hline Sulfonamide & Sulfadimidine & Human & Highly important $\mathrm{t}^{\mathrm{c}}$ & 6.04 & 20 & 0.18 & {$[39,40]$} \\
\hline Sulfonamide & Sulfaguanidine & Human & Highly important $\mathrm{t}^{\mathrm{b}, \mathrm{c}}$ & 0.57 & 1.55 & 0.25 & [39] \\
\hline Sulfonamide & Sulfamerazine & Human & Highly important $\mathrm{t}^{\mathrm{c}}$ & 0.66 & 0.14 & 0.09 & [39] \\
\hline Sulfonamide & Sulfamethazine & Human & Highly important $t^{\mathrm{b}, \mathrm{c}}$ & & 8.9 & & {$[42]$} \\
\hline Sulfonamide & Sulfamethoxazole & Human & Highly important $\mathrm{c}^{\mathrm{c}}$ & 2.8 & 0.84 & & [39] \\
\hline Sulfonamide & Sulfamonomethoxine & Human & Highly important $t^{\mathrm{b}, \mathrm{c}}$ & 0.9 & 4.08 & 0.06 & [39] \\
\hline Sulfonamide & Sulfanilamide & Human & Highly important $\mathrm{c}^{\mathrm{c}}$ & 1.59 & 0.04 & & [39] \\
\hline Sulfonamide & Sulfathiazole & Human & Highly important $\mathrm{c}^{\mathrm{c}}$ & & 12.4 & & {$[42]$} \\
\hline Tetracycline & Chlortetracycline & Human & Highly important $\mathrm{t}^{\mathrm{a}}$ & 94.71 & 281 & 208 & {$[51,56,57]$} \\
\hline Tetracycline & Doxycycline & Human & Highly important $\mathrm{t}^{\mathrm{a}}$ & 10.91 & 1.35 & 1.05 & {$[21,39]$} \\
\hline Tetracycline & Methacycline & Human & Highly important $\mathrm{t}^{\mathrm{a}}$ & 5.86 & 5.43 & 0.96 & [39] \\
\hline Tetracycline & Oxytetracycline & Human & Highly important $\mathrm{a}^{\mathrm{a}}$ & 10.56 & 59.06 & 225 & {$[39,53]$} \\
\hline Tetracycline & Tetracycline & Human & Highly important $\mathrm{a}^{\mathrm{a}}$ & 2.394 & 41.2 & & {$[41,58]$} \\
\hline Trimethoprim & Trimethoprim & Human & Highly important $\mathrm{c}^{\mathrm{c}}$ & 17 & 0.0025 & & {$[16,40]$} \\
\hline
\end{tabular}

${ }^{\mathrm{a}}$ Criterion 2 met in some countries

b Expected to be "highly important" but not explicitly listed in the WHO document

${ }^{\mathrm{c}}$ Criterion 1 met in some countries

incubated at colder temperatures. For these reasons, antibiotic treatment is attributed to temperature-dependent abiotic processes, such as sorption and degradation. Kim et al. [90] attributed the $\geq 95 \%$ treatment efficiencies of chlortetracycline, sulfamethazine, and tylosin to sorption mechanisms; however, the authors noted that microbial processes within compost piles produce a variety of compounds that interact and complex with antibiotics. Thus, while the sorption process is abiotic, antibiotic removal from the aqueous phase may be aided by biotic processes that co-occur in the compost pile. Furthermore, the authors [90] asserted that removal of charged molecules from the aqueous phase, such as tylosin which is predominantly cationic below $\mathrm{pH} 7.2$, is enhanced through ionic mechanisms. Li et al. [92] investigated sorption of tetracyclines in swine manure to compost and attributed $\geq 97 \%$ of the removal to the high organic content and cation exchange capacity of the 
Table 2 Overview of antibiotic removal in composting studies

\begin{tabular}{|c|c|c|c|c|c|c|c|}
\hline Compound & $\begin{array}{l}\text { Percent } \\
\text { removal }\end{array}$ & $\begin{array}{l}\text { Initial } \\
\text { concentration }(\mu \mathrm{g} / \mathrm{kg})\end{array}$ & $t_{1 / 2}$ (days) & $\begin{array}{l}\text { Length of } \\
\text { experiment (days) }\end{array}$ & $\begin{array}{l}\text { Scale of } \\
\text { experiment }\end{array}$ & $\begin{array}{l}\text { Type of } \\
\text { manure }\end{array}$ & Reference \\
\hline \multicolumn{8}{|l|}{ Coccidiostats } \\
\hline Monensin & $54-76$ & 11,900 & 22 & 35 & Lab-scale & Turkey & [87] \\
\hline Monensin & $54-76$ & 11,900 & 11 & 22 & Lab-scale & Turkey & [87] \\
\hline Monensin & $54-76$ & 11,900 & 19 & 35 & Lab-scale & Turkey & [87] \\
\hline Monensin & 90 & 250 & 14.7 & 141 & Pilot-scale & Horse & [77] \\
\hline Monensin & 90 & 250 & 30.1 & 141 & Pilot-scale & Horse & [77] \\
\hline Salinomycin & 100 & 22,000 & 1.3 & 38 & Lab-scale & Poultry & [88] \\
\hline \multicolumn{8}{|l|}{ Fluoroquinolones } \\
\hline Ciprofloxacin & 69 & 2000 & - & 56 & Lab-scale & Swine & [89] \\
\hline Ciprofloxacin & 83 & 20,000 & - & 56 & Lab-scale & Swine & [89] \\
\hline \multicolumn{8}{|l|}{ Macrolides } \\
\hline Tylosin & $54-76$ & 3700 & 23 & 35 & Lab-scale & Turkey & [87] \\
\hline Tylosin & $54-76$ & 3700 & 19 & 22 & Lab-scale & Turkey & [87] \\
\hline Tylosin & $54-76$ & 3700 & 16 & 35 & Lab-scale & Turkey & [87] \\
\hline Tylosin & 95 & 2000 & - & 40 & Lab-scale & Swine & [90] \\
\hline Tylosin & 95 & 10,000 & - & 40 & Lab-scale & Swine & [90] \\
\hline Tylosin & 95 & 20,000 & - & 40 & Lab-scale & Swine & [90] \\
\hline Tylosin & 95 & - & - & 80 & Full-scale & Swine & [90] \\
\hline Tylosin & 100 & 180 & 4.2 & 141 & Pilot-scale & Horse & [77] \\
\hline Tylosin & 100 & 230 & 9.8 & 141 & Pilot-scale & Horse & [77] \\
\hline \multicolumn{8}{|l|}{ Sulfonamides } \\
\hline Sulfadiazine & 100 & 2000 & - & 56 & Lab-scale & Swine & [89] \\
\hline Sulfadiazine & 100 & 20,000 & - & 56 & Lab-scale & Swine & [89] \\
\hline Sulfamethazine & 0 & 10,800 & - & 35 & Lab-scale & Turkey & [87] \\
\hline Sulfamethazine & 0 & 10,800 & - & 22 & Lab-scale & Turkey & [87] \\
\hline Sulfamethazine & 0 & 10,800 & - & 35 & Lab-scale & Turkey & [87] \\
\hline Sulfamethazine & 99 & 2000 & - & 40 & Lab-scale & Swine & [90] \\
\hline Sulfamethazine & 99 & 10,000 & - & 40 & Lab-scale & Swine & [90] \\
\hline Sulfamethazine & 99 & 20,000 & - & 40 & Lab-scale & Swine & [90] \\
\hline Sulfamethazine & 99 & - & - & 80 & Full-scale & Swine & {$[90]$} \\
\hline \multicolumn{8}{|l|}{ Tetracyclines } \\
\hline Chlortetracycline & 100 & 7.9 & - & - & Full-scale & Swine & [21] \\
\hline Chlortetracycline & 0 & 67.4 & - & - & Full-scale & Swine & [21] \\
\hline Chlortetracycline & 96.3 & 8992 & - & - & Full-scale & Swine & [21] \\
\hline Chlortetracycline & 98.5 & 60,000 & - & 45 & Lab-scale & Hen & [85] \\
\hline Chlortetracycline & 97.3 & 60,000 & - & 45 & Lab-scale & Swine & {$[85]$} \\
\hline Chlortetracycline & $>99$ & 1500 & 1 & & Lab-scale & Turkey & [87] \\
\hline Chlortetracycline & $>99$ & 1500 & 0.8 & 22 & Lab-scale & Turkey & [87] \\
\hline Chlortetracycline & $>99$ & 1500 & 0.9 & 35 & Lab-scale & Turkey & [87] \\
\hline Chlortetracycline & 96 & 2000 & - & 40 & Lab-scale & Swine & [90] \\
\hline Chlortetracycline & 96 & 10,000 & - & 40 & Lab-scale & Swine & [90] \\
\hline Chlortetracycline & 96 & 20,000 & - & 40 & Lab-scale & Swine & [90] \\
\hline Chlortetracycline & 96 & - & - & 80 & Full-scale & Swine & [90] \\
\hline Chlortetracycline & 100 & 330 & 5.1 & 141 & Pilot-scale & Horse & {$[77]$} \\
\hline Chlortetracycline & 100 & 330 & 8.4 & 141 & Pilot-scale & Horse & {$[77]$} \\
\hline Chlortetracycline & 100 & 250 & 13.4 & 182 & Field-scale & Beef cattle & [77] \\
\hline Chlortetracycline & 100 & 300 & 13.5 & 182 & Field-scale & Beef cattle & {$[77]$} \\
\hline Chlortetracycline & 100 & 20 & 5.8 & 182 & Field-scale & Dairy cattle & {$[77]$} \\
\hline Chlortetracycline & 100 & 20 & 6.8 & 182 & Field-scale & Dairy cattle & {$[77]$} \\
\hline Chlortetracycline & 100 & 10,000 & - & 56 & Lab-scale & Swine & [89] \\
\hline Chlortetracycline & 100 & 100,000 & - & 56 & Lab-scale & Swine & [89] \\
\hline Chlortetracycline & 92.6 & 94,710 & 11.0 & 42 & Lab-scale & Broiler & [56] \\
\hline Chlortetracycline & 100 & 53,100 & 4.39 & 42 & Lab-scale & Layer-hen & {$[56]$} \\
\hline Chlortetracycline & 100 & 100,000 & 12.0 & 42 & Lab-scale & Layer-hen & [56] \\
\hline Chlortetracycline & 100 & 150,300 & 12.2 & 42 & Lab-scale & Layer-hen & [56] \\
\hline Chlortetracycline & 27 & 879,600 & 86.6 & 42 & Lab-scale & Swine (hog) & [56] \\
\hline $\begin{array}{l}\text { Chlortetracycline }+4- \\
\text { epi-chlortetracycline }\end{array}$ & 99.4 & 113,000 & 4 & 30 & Lab-scale & Beef cattle & [51] \\
\hline $\begin{array}{l}\text { Chlortetracycline }+4- \\
\text { epi-chlortetracycline }\end{array}$ & 99.7 & 192,000 & 2.6 & 28 & Lab-scale & Beef cattle & [77] \\
\hline $\begin{array}{l}\text { Chlortetracycline }+4- \\
\text { epi-chlortetracycline }\end{array}$ & 99.7 & 192,000 & 3.0 & 28 & Lab-scale & Beef cattle & [77] \\
\hline $\begin{array}{l}\text { Chlortetracycline }+4- \\
\text { epi-chlortetracycline }\end{array}$ & 97.6 & 192,000 & 3.8 & 28 & Lab-scale & Beef cattle & [77] \\
\hline
\end{tabular}


Table 2 (continued)

\begin{tabular}{|c|c|c|c|c|c|c|c|}
\hline Compound & $\begin{array}{l}\text { Percent } \\
\text { removal }\end{array}$ & $\begin{array}{l}\text { Initial } \\
\text { concentration }(\mu \mathrm{g} / \mathrm{kg})\end{array}$ & $t_{1 / 2}$ (days) & $\begin{array}{l}\text { Length of } \\
\text { experiment (days) }\end{array}$ & $\begin{array}{l}\text { Scale of } \\
\text { experiment }\end{array}$ & $\begin{array}{l}\text { Type of } \\
\text { manure }\end{array}$ & Reference \\
\hline $\begin{array}{l}\text { Chlortetracycline }+4- \\
\text { epi-chlortetracycline }\end{array}$ & 96 & 192,000 & 4.0 & 28 & Lab-scale & Beef cattle & {$[77]$} \\
\hline Doxycycline & 100 & 5.1 & - & - & Full-scale & Swine & {$[21]$} \\
\hline Doxycycline & 99.8 & 1351 & - & - & Full-scale & Swine & [21] \\
\hline Doxycycline & 93.9 & 1223 & - & - & Full-scale & Swine & [21] \\
\hline Iso-chlortetracycline & 100 & 36,800 & - & 28 & Lab-scale & Beef cattle & {$[77]$} \\
\hline Iso-chlortetracycline & 100 & 36,800 & - & 28 & Lab-scale & Beef cattle & {$[77]$} \\
\hline Iso-chlortetracycline & 100 & 36,800 & - & 28 & Lab-scale & Beef cattle & {$[77]$} \\
\hline Iso-chlortetracycline & 100 & 36,800 & - & 28 & Lab-scale & Beef cattle & {$[77]$} \\
\hline Iso-chlortetracycline & 97.5 & 12,000 & - & 30 & Lab-scale & Beef cattle & {$[51]$} \\
\hline Methacycline & 100 & 12 & - & - & Full-scale & Swine & [21] \\
\hline Methacycline & 100 & 71.1 & - & - & Full-scale & Swine & [21] \\
\hline Oxytetracycline & 13.0 & 74.9 & - & - & Full-scale & Swine & [21] \\
\hline Oxytetracycline & 97.2 & 2544 & - & - & Full-scale & Swine & {$[21]$} \\
\hline Oxytetracycline & 40.8 & 39.2 & - & - & Full-scale & Swine & [21] \\
\hline Oxytetracycline & 97.2 & 60,000 & - & 45 & Lab-scale & Hen & [85] \\
\hline Oxytetracycline & 96.2 & 60,000 & - & 45 & Lab-scale & Swine & [85] \\
\hline Oxytetracycline & 100 & 1000 & 15.2 & 182 & Field-scale & Beef cattle & [91] \\
\hline Oxytetracycline & 100 & 800 & 31.1 & 182 & Field-scale & Beef cattle & [91] \\
\hline Oxytetracycline & 100 & 250 & 9.8 & 182 & Field-scale & Dairy cattle & [91] \\
\hline Oxytetracycline & 100 & 200 & 17.7 & 182 & Field-scale & Dairy cattle & [91] \\
\hline Oxytetracycline & 98.3 & 18,000 & 4.7 & 28 & Lab-scale & Beef cattle & {$[77]$} \\
\hline Oxytetracycline & 98.3 & 18,000 & 4.7 & 28 & Lab-scale & Beef cattle & {$[77]$} \\
\hline Oxytetracycline & 97.8 & 18,000 & 5.6 & 28 & Lab-scale & Beef cattle & {$[77]$} \\
\hline Oxytetracycline & 91.1 & 18,000 & 7.5 & 28 & Lab-scale & Beef cattle & [77] \\
\hline Oxytetracycline & 99.8 & 115,000 & 3.2 & 35 & Lab-scale & Beef cattle & [53] \\
\hline Tetracycline & 0 & 2.2 & - & - & Full-scale & Swine & {$[21]$} \\
\hline Tetracycline & 55.1 & 122 & - & - & Full-scale & Swine & {$[21]$} \\
\hline Tetracycline & 95.8 & 1210 & - & - & Full-scale & Swine & [21] \\
\hline Tetracycline & 93.8 & 60,000 & - & 45 & Lab-scale & Hen & [85] \\
\hline Tetracycline & 95.7 & 60,000 & - & 45 & Lab-scale & Pig & [85] \\
\hline Tetracycline & 100 & 65 & 6.5 & 182 & Field-scale & Beef cattle & [91] \\
\hline Tetracycline & 100 & 30 & 17.2 & 182 & Field-scale & Beef cattle & [91] \\
\hline Tetracycline & 100 & 5 & - & 182 & Field-scale & Dairy cattle & [91] \\
\hline Tetracycline & 100 & 7 & - & 182 & Field-scale & Dairy cattle & [91] \\
\hline
\end{tabular}

compost. Chlortetracycline sorbed more strongly than oxytetracycline and tetracycline due to the electron withdrawing characteristics of the chlorine atom, which results in higher polarity.

Kim et al. [90], Selvam et al. [89], and Bao et al. [56] found comparable treatment efficiencies during composting processes with different initial antibiotic concentrations. However, Selvam et al. [89] reported that high initial antimicrobial concentrations (i.e., $50 \mathrm{mg} / \mathrm{kg}$ of chlortetracycline and $10 \mathrm{mg} / \mathrm{kg}$ each of sulfadiazine and ciprofloxacin) resulted in a lag phase before degradation. Conversely, Qiao et al. [21] observed treatment efficiencies of approximately $25 \%$ when initial antibiotic concentrations were less than $0.12 \mathrm{mg} / \mathrm{kg}$ compared to $91-94 \%$ treatment at higher initial antibiotic concentrations. The authors concluded that additional removal of antibiotics at such concentrations is difficult in composting systems.

Ramaswamy et al. [88] and Dolliver et al. [87] found comparable antibiotic treatment efficiencies between managed composting (i.e., turning and adjustment of the moisture content) and piling practices with no additional management. These findings come despite the higher temperatures achieved in more intensive manure management. Storteboom et al. [91] found that the impact of management intensity varied by antibiotic: no significant differences were observed for monensin, but improved treatment efficiencies were reported for chlortetracycline and tylosin in managed compost piles. For all three antibiotics, the rate of degradation was higher with more intensive management practices. Arikan et al. [77] investigated different arrangement strategies for manure piles, including placing the pile on straw to reduce heat loss, covering the pile with straw to reduce heat loss, and mixing straw into the pile to increase aeration. In all cases, comparable degradation was reported and these removals were not significantly different than the control pile, which was placed directly on the floor, uncovered and unamended. Thus, low-intensity management practices may still achieve substantial treatment of antibiotics.

\section{Anaerobic Digestion}

Anaerobic digestion is a two-step process, in which a fraction of the organic content of the manure is first hydrolyzed and 
converted into volatile fatty acids (VFAs) by acidogenic bacteria [93]. Methanogenic bacteria then convert VFAs into methane [93]. In comparison to composting or long-term storage of manure in lagoons, anaerobic digestion is a more sensitive process that requires operational precision. Nevertheless, anaerobic digestion provides certain advantages, including production of methane, which offsets energy costs, reduces greenhouse gas emissions, and increases the economic sustainability of farm operations [94].

As summarized in Table 3, removal of various antibiotics during anaerobic digestion has been investigated for swine [43, 47, 96-99] and cattle manure [54, 78, 95] in 20-216-day experiments. Nearly all analyses were performed at mesophilic temperatures [43, 54, 78, 95-99], although psychrophilic [47] temperatures have been examined in select studies. Anaerobic sequencing batch reactors, which decouple the solids' residence time and hydraulic retention time and allow for smaller reactor footprints [100], have also been explored for the removal of antibiotics [43, 101, 102]. Nearly complete removal was observed for the following antimicrobials: ampicillin [95], florfenicol [95], sulfadimethoxine [97], sulfamerazine [97], sulfamethoxazole [97], sulfamethoxydiazine [98], tetracycline [98], trimethoprim [97], and tylosin [43, 47, 95]. Negligible removals were identified for iso-chlortetracycline [78] and sulfathiazole [97]; furthermore, less than $20 \%$ removal was reported for spectinomycin [96] and sulfamethazine [95, 97]. One study observed $57 \%$ degradation of chlortetracycline at psychrophilic temperatures [47] compared to 74-92\% at mesophilic temperatures. Sara et al. [96] found that thermal pretreatment prior to anaerobic digestion enhanced antibiotic removal. These findings indicate that antibiotic biodegradation efficiencies are temperature dependent, with increased removal at higher temperatures.

Angenent et al. [43] attributed high treatability of tylosin A to biodegradation. Sara et al. [96] also concluded that observed removals of ceftiofur, danofloxacin, lincomycin, and spectinomycin were largely attributable to biodegradation. Metabolites of ampicillin [95], chlortetracycline [78], florfenicol [95], sulfadiazine [97], and tylosin [95] have been reported, reinforcing the contribution of biodegradation processes. Wang et al. [45] found a lower reduction in methane production when tylosin A was added directly to manure before anaerobic digestion than when tylosin A was fed to animals, even when the influent tylosin concentrations to the digesters were identical. This difference was attributed to the presence of metabolites in the manure. However, biodegradation may be class- and compound-specific. For example, Mitchell et al. [95] found minimal biodegradation of sulfamethazine and $20 \%$ removal by sorption.

In general, the preponderance of the literature $[49,55,74,96$, 101-113] focuses on the effects of antibiotics on the anaerobic digestion process rather than the fate of antibiotics during treatment. Individual antibiotics demonstrate a range of impacts on biogas production, from no effect to complete inhibition.
Ampicillin [95], carbadox [102], cefazolin [113], ceftiofur [96], chloramphenicol [109], chlortetracycline [49, 109], erythromycin [109], lincomycin [102], oxytetracycline [107], sulfamethazine $[95,102]$, and tylosin $[43,47,102,109]$ did not reduce biogas production (under the tested conditions). Varel and Hashimoto [108] found that monensin completely inhibited methane production, although they proposed that microbial adaptation could occur. A number of studies reported partial inhibition of biogas production by amoxicillin [107]; ampicillin [105]; chloramphenicol [105]; chlortetracycline [47, 99, 103, 104, 108]; danofloxacin [96]; enrofloxacin [103]; florfenicol [95]; micospectone [96], which is a combination of spectinomycin and lincomycin; oxytetracycline [54, 99, 105, 111, 113, 114]; penicillin [102, 105]; sulfamethoxydiazine [98]; tetracycline [98, 102, 105]; thiamphenicol [107]; and tylosin [45, 95, 101]. Unsurprisingly, greater inhibitory effects have been identified at higher antibiotic concentrations for several antibiotics: chlortetracycline [99, 103, 104], enrofloxacin [103], florfenicol [95], oxytetracycline [55, 99, 111], and tylosin [101].

The mechanism of antibiotic impacts on anaerobic digestion is convoluted. While the presence of antibiotics can reduce biogas production, substantial evidence exists that antimicrobial compounds (at some concentrations) do not affect process stability as measured by biogas composition [47, 54, 55, 105], $\mathrm{pH}[45$, 102, 104, 113], VFA concentrations [102, 113], soluble organic content in the digestion process [54, 102], volatile solids removal $[43,102]$, or nitrogen content $[45,103]$. However, the presence of antibiotics has, under certain conditions, been shown to affect acetate uptake [101, 104], pH [47], chemical oxygen demand $[47,109]$, volatile solids removal $[47,105]$, VFA levels [47, $105,109]$, or methane content $[104,105]$. While biogas production rates $[95,106]$ and composition [49] may initially be affected by the presence of antibiotics, this impact can be overcome by implementing an acclimation period. This scenario is reinforced by identified changes in microbial communities following introduction of chlortetracycline [47, 103, 104], oxytetracycline [111], and tylosin [45, 47]; however, Bauer et al. [103] found that enrofloxacin did not alter the microbial community structure. Again, these results suggest a dependence of microbial population changes on antimicrobial class. With the advent of highthroughput analytical techniques, future research efforts to document the impacts of antimicrobials on microbial community structure and function will help elucidate impacts on digester performance and antibiotic degradation.

\section{Anaerobic and Aerobic Lagoons}

Lagoons are a common means of manure storage. Some lagoons are emptied twice a year [46], while others are designed to never be emptied and rely on evaporation or infiltration for dissipation of the liquid content, with gradual accumulation of solids [115]. Treatment of antibiotics in anaerobic lagoons $[44,46,48,116,117]$ has been 
Table 3 Summary of antibiotic removal by anaerobic digestion

\begin{tabular}{|c|c|c|c|c|c|c|c|}
\hline Compound & $\begin{array}{l}\text { Percent } \\
\text { removal }\end{array}$ & $\begin{array}{l}\text { Initial concentration } \\
(\mathrm{mg} / \mathrm{L})\end{array}$ & $t_{1 / 2}$ (days) & Temperature $\left({ }^{\circ} \mathrm{C}\right)$ & Configuration & $\begin{array}{l}\text { Type of } \\
\text { manure }\end{array}$ & Reference \\
\hline \multicolumn{8}{|l|}{ Amphenicols } \\
\hline Florfenicol & 100 & 0.36 & - & 37 & Batch (40 days) & Cattle & {$[95]$} \\
\hline Florfenicol & 100 & 3.6 & - & 37 & Batch (40 days) & Cattle & {$[95]$} \\
\hline Florfenicol & 100 & 36 & - & 37 & Batch (40 days) & Cattle & {$[95]$} \\
\hline Florfenicol & 100 & 180 & - & 37 & Batch (40 days) & Cattle & {$[95]$} \\
\hline Florfenicol & 100 & 360 & - & 37 & Batch (40 days) & Cattle & {$[95]$} \\
\hline \multicolumn{8}{|l|}{ Beta-lactams } \\
\hline Ampicillin & 100 & 0.35 & - & 37 & Batch (40 days) & Cattle & {$[95]$} \\
\hline Ampicillin & 100 & 3.5 & - & 37 & Batch (40 days) & Cattle & {$[95]$} \\
\hline Ampicillin & 100 & 35 & - & 37 & Batch (40 days) & Cattle & {$[95]$} \\
\hline Ampicillin & 100 & 175 & - & 37 & Batch (40 days) & Cattle & {$[95]$} \\
\hline Ampicillin & 100 & 350 & - & 37 & Batch (40 days) & Cattle & {$[95]$} \\
\hline Ceftiofur & 72.35 & 1.7 & - & 37 & Batch (60 days) & Swine & [96] \\
\hline Ceftiofur & 72.46 & 6.9 & - & 37 & Batch (60 days) & Swine & [96] \\
\hline Ceftiofur & 73.77 & 13.8 & - & 37 & Batch (60 days) & Swine & [96] \\
\hline Ceftiofur & 80.22 & 13.8 & - & 37 & Batch (60 days) & Swine & [96] \\
\hline Ceftiofur & 79.71 & 13.8 & - & 37 & Batch (60 days) & Swine & {$[96]$} \\
\hline \multicolumn{8}{|l|}{ Fluoroquinolones } \\
\hline Danofloxacin & 33.95 & 1.1 & - & 37 & Batch (60 days) & Swine & [96] \\
\hline Danofloxacin & 28.17 & 4.3 & - & 37 & Batch (60 days) & Swine & {$[96]$} \\
\hline Danofloxacin & 32.27 & 8.5 & - & 37 & Batch (60 days) & Swine & {$[96]$} \\
\hline Danofloxacin & 45.55 & 8.5 & - & 37 & Batch (60 days) & Swine & {$[96]$} \\
\hline Danofloxacin & 41.94 & 8.5 & - & 37 & Batch (60 days) & Swine & {$[96]$} \\
\hline \multicolumn{8}{|l|}{ Lincosamides } \\
\hline Spectinomycin & 17.61 & 9.2 & - & 37 & Batch (60 days) & Swine & {$[96]$} \\
\hline Spectinomycin & 18.46 & 37 & - & 37 & Batch (60 days) & Swine & {$[96]$} \\
\hline Spectinomycin & 16.26 & 73.9 & - & 37 & Batch (60 days) & Swine & {$[96]$} \\
\hline Spectinomycin & 18.78 & 73.9 & - & 37 & Batch (60 days) & Swine & [96] \\
\hline Spectinomycin & 18.54 & 73.9 & - & 37 & Batch (60 days) & Swine & [96] \\
\hline Lincomycin & 32.81 & 4.6 & - & 37 & Batch (60 days) & Swine & {$[96]$} \\
\hline Lincomycin & 34.32 & 18.5 & - & 37 & Batch (60 days) & Swine & [96] \\
\hline Lincomycin & 33.86 & 37 & - & 37 & Batch (60 days) & Swine & [96] \\
\hline Lincomycin & 34.6 & 37 & - & 37 & Batch (60 days) & Swine & {$[96]$} \\
\hline Lincomycin & 34.27 & 37 & - & 37 & Batch (60 days) & Swine & {$[96]$} \\
\hline \multicolumn{8}{|l|}{ Macrolides } \\
\hline Tylosin & 99.4 & 1.6 & 0.10 & 25 & ASBR & Swine & [43] \\
\hline Tylosin & 99.1 & 1.1 & - & $10-20$ & Batch (216 days) & Swine & {$[47]$} \\
\hline Tylosin & 100 & 0.92 & - & 37 & Batch (40 days) & Cattle & [95] \\
\hline Tylosin & 100 & 9.2 & - & 37 & Batch (40 days) & Cattle & {$[95]$} \\
\hline Tylosin & 100 & 92 & - & 37 & Batch (40 days) & Cattle & {$[95]$} \\
\hline Tylosin & 100 & 460 & - & 37 & Batch (40 days) & Cattle & {$[95]$} \\
\hline Tylosin & 100 & 920 & - & 37 & Batch (40 days) & Cattle & {$[95]$} \\
\hline \multicolumn{8}{|l|}{ Sulfonamides } \\
\hline Sulfadimethoxine & 99.6 & 0.40 & - & 37 & Batch (34 days) & Swine & [97] \\
\hline Sulfadimethoxine & 99.6 & 2.0 & - & 37 & Batch (34 days) & Swine & [97] \\
\hline Sulfamerazine & 100 & 0.40 & - & 37 & Batch (34 days) & Swine & [97] \\
\hline Sulfamerazine & 100 & 2.0 & - & 37 & Batch (34 days) & Swine & [97] \\
\hline Sulfamethazine & 20 & 0.28 & - & 37 & Batch (40 days) & Cattle & [95] \\
\hline
\end{tabular}


Table 3 (continued)

\begin{tabular}{|c|c|c|c|c|c|c|c|}
\hline Compound & $\begin{array}{l}\text { Percent } \\
\text { removal }\end{array}$ & $\begin{array}{l}\text { Initial concentration } \\
(\mathrm{mg} / \mathrm{L})\end{array}$ & $t_{1 / 2}$ (days) & Temperature $\left({ }^{\circ} \mathrm{C}\right)$ & Configuration & $\begin{array}{l}\text { Type of } \\
\text { manure }\end{array}$ & Reference \\
\hline Sulfamethazine & 20 & 2.8 & - & 37 & Batch (40 days) & Cattle & {$[95]$} \\
\hline Sulfamethazine & 20 & 28 & - & 37 & Batch (40 days) & Cattle & {$[95]$} \\
\hline Sulfamethazine & 20 & 140 & - & 37 & Batch (40 days) & Cattle & {$[95]$} \\
\hline Sulfamethazine & 20 & 280 & - & 37 & Batch (40 days) & Cattle & {$[95]$} \\
\hline Sulfamethazine & 0 & 0.40 & - & 37 & Batch (34 days) & Swine & [97] \\
\hline Sulfamethazine & 0 & 2.0 & - & 37 & Batch (34 days) & Swine & [97] \\
\hline Sulfamethoxazole & 99.9 & 0.40 & - & 37 & Batch (34 days) & Swine & {$[97]$} \\
\hline Sulfamethoxazole & 99.9 & 2.0 & - & 37 & Batch (34 days) & Swine & [97] \\
\hline Sulfamethoxydiazine & 100 & 50.0 & - & 25 & Batch (20 days) & Swine & {$[98]$} \\
\hline Sulfamethoxypyridazine & 72.3 & 0.40 & - & 37 & Batch (34 days) & Swine & [97] \\
\hline Sulfamethoxypyridazine & 72.3 & 2.0 & - & 37 & Batch (34 days) & Swine & [97] \\
\hline Sulfathiazole & 0 & 2.0 & - & 37 & Batch (34 days) & Swine & [97] \\
\hline \multicolumn{8}{|l|}{ Tetracyclines } \\
\hline 4-Epi-chlortetracycline & 39.0 & 4.11 & 39 & 35 & Batch (33 days) & Beef cattle & {$[78]$} \\
\hline 4-Epi-chlortetracycline & 30.4 & 0.56 & 50 & 35 & Batch (33 days) & Beef cattle & {$[78]$} \\
\hline Chlortetracycline & 57.0 & 28 & - & $10-20$ & Batch (216 days) & Swine & {$[47]$} \\
\hline Chlortetracycline & 74 & 5.86 & 18 & 35 & Batch (33 days) & Beef cattle & {$[78]$} \\
\hline Chlortetracycline & 75 & 0.98 & 18 & 35 & Batch (33 days) & Beef cattle & {$[78]$} \\
\hline Chlortetracycline & 90.8 & 9.8 & - & 35 & Batch (21 days) & Swine & [99] \\
\hline Chlortetracycline & 91.3 & 46.1 & - & 35 & Batch (21 days) & Swine & [99] \\
\hline Chlortetracycline & 89.9 & 74.0 & - & 35 & Batch (21 days) & Swine & [99] \\
\hline Iso-chlortetracycline & 0 & 2.36 & - & 35 & Batch (33 days) & Beef cattle & {$[78]$} \\
\hline Iso-chlortetracycline & 0 & 0.28 & - & 35 & Batch (33 days) & Beef cattle & {$[78]$} \\
\hline Oxytetracycline & 59 & 9.8 & 56 & 35 & Batch (64 days) & Beef cattle & {$[54]$} \\
\hline Oxytetracycline & 57.8 & 13.5 & - & 35 & Batch (21 days) & Swine & [99] \\
\hline Oxytetracycline & 53.2 & 56.9 & - & 35 & Batch (21 days) & Swine & [99] \\
\hline Oxytetracycline & 67.6 & 95.0 & - & 35 & Batch (21 days) & Swine & [99] \\
\hline Tetracycline & 100 & 50 & - & 25 & Batch (20 days) & Swine & [98] \\
\hline \multicolumn{8}{|l|}{ Trimethoprim } \\
\hline Trimethoprim & 100 & 0.56 & - & 37 & Batch (34 days) & Swine & [97] \\
\hline Trimethoprim & 100 & 2.8 & - & 37 & Batch (34 days) & Swine & {$[97]$} \\
\hline
\end{tabular}

evaluated for swine and dairy manure. Bacitracin, chlortetracycline, oxytetracycline, spectinomycin, and tylosin have demonstrated $70-100 \%$ treatment efficiencies in studies lasting 12-240 days [44, 46, 48, 116]. In most cases, removal was biphasic, with a period of rapid concentration change in the first week followed by a prolonged second stage. Lincomycin diverged from this pattern: $40 \%$ was removed within the first 6 days, but concentrations were stable thereafter [46]. Less than $50 \%$ of tetracycline was degraded in an 8-day experiment [117]. Pei et al. [116] found that temperature affected sulfamethoxazole treatment in lagoons: $25 \%$ degradation was observed at $4{ }^{\circ} \mathrm{C}$, but $85 \%$ occurred at $20{ }^{\circ} \mathrm{C}$. A similar experiment carried out with oxytetracycline showed complete removal at 4 and $20{ }^{\circ} \mathrm{C}$.
Loftin et al. [44] inhibited microbial activity in samples with high solids content and found that a significant proportion of tylosin removal occurred via sorption. However, the authors observed faster treatment kinetics in uninhibited samples, thereby indicating the additional contribution of biodegradation processes, which is consistent with the biodegradability of tylosin demonstrated for anaerobic digestion [43]. Evaluation of antibiotic effects on biological processes in anaerobic lagoons has been correlated to methane production. Loftin et al. [44] found that chlortetracycline, lincomycin, oxytetracycline, sulfadimethoxine, sulfamethazine, sulfathiazole, tetracycline, and tylosin reduced methane production by 10 $65 \%$. In addition, lagoons treating manure from farms with a history of antibiotic consumption were found to experience less inhibition of methane production than lagoons with 
limited antibiotic exposure. These results further verify that microbial populations can acclimate to manure containing antibiotics over long timeframes.

Limited data is available on antibiotic treatment in aerated lagoons, which are more difficult to manage due to higher operational costs associated with mixing, maintenance, and aeration. In laboratory studies with swine and dairy cattle manure, monensin [116], oxytetracycline [116], and tylosin [44] were completely removed over the course of 12-150 days. Treatment efficiencies of less than $70 \%$ were observed for tetracycline in an 8-day experiment [117]. As in anaerobic lagoons, a temperature dependence was observed for sulfamethoxazole with complete removal at $20{ }^{\circ} \mathrm{C}$, but only $35 \%$ at $4{ }^{\circ} \mathrm{C}$; complete removal of oxytetracycline occurred at both conditions [116].

Loftin et al. [44], Kühne et al. [117], and Pei et al. [116] evaluated treatment of oxytetracycline, sulfamethoxazole, tetracycline, and tylosin in anaerobic and aerobic lagoons, effectively establishing a baseline for comparing performance. Oxytetracycline was fully removed for both conditions, but treatment efficiencies for sulfamethoxazole, tetracycline, and tylosin were higher at aerobic conditions. The half-life, or $t_{1 / 2}$, for tetracycline [117] and the time required for a $90 \%$ decrease in tylosin concentration under aerobic conditions were approximately half of those calculated for anaerobic conditions, indicating that aerobic lagoons are more effective at treating antibiotic residues; however, the operational complexity and maintenance costs associated with aerobic lagooning may limit implementation.

Pei et al. [116] and Loftin et al. [44] compared antimicrobial degradation in both anaerobic and aerobic lagoons with and without sodium azide (to inhibit biological activity) and found conflicting results. Pei et al. reported higher treatment efficiencies of monensin, oxytetracycline, sulfamethoxazole, and tylosin in the uninhibited experiments, indicating that biodegradation played a significant role in removal. On the other hand, Loftin et al. observed similar removal efficiencies for both conditions, suggesting that biodegradation played a relatively minor role in tylosin treatment. For these reasons, the contribution of biodegradation to overall removal likely depends on the physicochemical characteristics of individual antibiotics and lagoon conditions. Analysis of settled solids in operating lagoons at eight different animal (i.e., poultry, swine, and cattle) feeding operations [118] demonstrated tetracycline concentrations of $\geq 3000 \mu \mathrm{g} / \mathrm{kg}$ (dry weight) and sulfonamide levels of $\geq 800 \mu \mathrm{g} / \mathrm{kg}$ (dry weight). Ciprofloxacin, enrofloxacin, lincomycin, trimethoprim, and tylosin A were also detected, although at lower levels. These detections indicate that antimicrobial sorption to lagoon solids plays a significant role in the removal of these antibiotics from lagoon effluent. Similarly, Peak et al. [119] evaluated tetracycline presence in full-scale, functioning lagoons from eight cattle farms and found concentrations as high as $17 \mu \mathrm{g} / \mathrm{L}$. These farms were categorized as "high use" for tetracycline, indicating that high treatment efficiencies are likely (although initial concentrations were not reported). These findings also establish that antibiotic residues are present in lagoon effluent, which is often land-applied as a soil amendment and/or fertilizer.

\section{Comparison of Treatment Methods}

Tables 2, 3, and 4 show that chlortetracycline, oxytetracycline, tetracycline, and tylosin have been widely evaluated in composting, anaerobic digestion, and lagoon studies. Direct comparison of these studies obfuscates conclusions about the most effective treatment method. Tetracycline was completely removed from the treated effluent in one anaerobic digestion study while demonstrating a treatment efficiency of $>90 \%$ in most composting studies; however, lower removals were reported in aerobic and anaerobic lagoons. For chlortetracycline, treatment was highest (generally $90-100 \%$ ) in composting systems. Chlortetracycline removal from the treated effluent in anaerobic digestion and anaerobic lagoons reached $90 \%$ in some cases but tended to be lower overall. Complete removal of oxytetracycline was observed in anaerobic/aerobic lagoons and nearly all composting studies, but lower treatment efficiencies were reported for anaerobic digestion. Similar findings are observed for tylosin, which was completely removed in most anaerobic digestion and aerobic lagoon studies, but not all of the composting investigations.

In general, antibiotic treatment efficiencies during composting were more consistent and higher in comparison to anaerobic digestion and lagoons. However, given that observed removals rely on sorption, antibiotics are not transformed through the composting process, and thus antibiotic residues remain in composted manure. The resulting bioavailability of antibiotics, following land application, depends on the reversibility of the sorption reaction. On the other hand, biodegradation is more prominent in anaerobic digestion, and both sorption and biodegradation are relevant in lagoons. In both processes, antibiotic transformation occurs, resulting in lower antibiotic concentrations in treated manure and process effluent; however, the presence of biologically active metabolites in treated manure needs to be more fully investigated. This area has been partially investigated for some fluoroquinolones and tetracyclines, but for other antibiotics, identification of degradation products in agricultural waste management is a primary research gap.

Anaerobic lagoons are the most common means of manure management due to the low maintenance needs and costs. However, our aggregate analysis has shown that anaerobic lagoons offer the lowest antibiotic treatment efficiencies. Thus, continued use of anaerobic lagoons ensures that antibiotics remain in manure solids and lagoon effluent during field application. For that reason, manure from facilities that 
Table 4 Antibiotic removal in anaerobic and aerobic lagoon systems

\begin{tabular}{|c|c|c|c|c|c|c|c|c|}
\hline Compound & $\begin{array}{l}\text { Percent } \\
\text { removal }\end{array}$ & $\begin{array}{l}\text { Initial concentration } \\
(\mathrm{mg} / \mathrm{L})\end{array}$ & $t_{1 / 2}$ (days) & $\begin{array}{l}\text { Length of } \\
\text { experiment (days) }\end{array}$ & Temperature $\left({ }^{\circ} \mathrm{C}\right)$ & Conditions & Type of manure & Reference \\
\hline \multicolumn{9}{|l|}{ Coccidiostats } \\
\hline Monensin & 100 & 20 & - & - & 20 & Aerobic & Dairy cattle & [116] \\
\hline \multicolumn{9}{|l|}{ Lincosamides } \\
\hline Lincomycin & 37.7 & 0.053 & - & 154 & 20 & Anaerobic & Swine & {$[46]$} \\
\hline Spectinomycin & 100 & 0.387 & - & 154 & 20 & Anaerobic & Swine & {$[46]$} \\
\hline \multicolumn{9}{|l|}{ Macrolides } \\
\hline Tylosin & 90 & $10^{\mathrm{a}}$ & 9.7 & 40 & 37 & Anaerobic & Swine & {$[48]$} \\
\hline Tylosin & $>70$ & 20 & $12.9^{\mathrm{b}}$ & 12 & 22 & Anaerobic & Swine & {$[44]$} \\
\hline Tylosin & $>90$ & 20 & $1.7^{\mathrm{b}}$ & 12 & 22 & Anaerobic & Swine & {$[44]$} \\
\hline Tylosin & $>90$ & 195 & $1.7^{\mathrm{b}}$ & 12 & 22 & Anaerobic & Swine & {$[44]$} \\
\hline Tylosin & 99 & 12 & - & 240 & 22 & Anaerobic & Swine & {$[44]$} \\
\hline Tylosin & 100 & 20 & $0.5-1.1^{\mathrm{b}}$ & 12 & 22 & Aerobic & Swine & {$[44]$} \\
\hline Tylosin & 100 & 20 & $0.5-1.1^{\mathrm{b}}$ & 12 & 22 & Aerobic & Swine & {$[44]$} \\
\hline \multicolumn{9}{|l|}{ Polypeptides } \\
\hline Bacitracin F & 100 & $50^{\mathrm{a}}$ & 1.9 & 40 & 37 & Anaerobic & Swine & {$[48]$} \\
\hline \multicolumn{9}{|l|}{ Sulfonamides } \\
\hline Sulfamethoxazole & 25 & 20 & - & 150 & 4 & Anaerobic & Dairy cattle & [116] \\
\hline Sulfamethoxazole & 35 & 20 & - & 150 & 4 & Aerobic & Dairy cattle & [116] \\
\hline Sulfamethoxazole & 85 & 20 & - & 150 & 20 & Anaerobic & Dairy cattle & [116] \\
\hline Sulfamethoxazole & 100 & 20 & - & 150 & 20 & Aerobic & Dairy cattle & [116] \\
\hline \multicolumn{9}{|l|}{ Tetracyclines } \\
\hline Chlortetracycline & $>80$ & $300^{\mathrm{a}}$ & 1 & 40 & 37 & Anaerobic & Swine & {$[48]$} \\
\hline Oxytetracycline & 100 & 20 & - & 150 & 4 & Anaerobic & Dairy cattle & [116] \\
\hline Oxytetracycline & 100 & 20 & - & 150 & 4 & Aerobic & Dairy cattle & [116] \\
\hline Oxytetracycline & 100 & 20 & - & 75 & 20 & Anaerobic & Dairy cattle & [116] \\
\hline Oxytetracycline & 100 & 20 & - & 75 & 20 & Aerobic & Dairy cattle & [116] \\
\hline Tetracycline & 49.1 & 200 & 9 & 8 & Ambient & Anaerobic & Swine & [117] \\
\hline Tetracycline & 68.7 & 200 & 4.5 & 8 & Ambient & Aerobic & Swine & [117] \\
\hline
\end{tabular}

${ }^{a}$ Milligram per kilogram dry weight basis

${ }^{\mathrm{b}} t_{90}$ (time for $90 \%$ removal)

employ antimicrobial growth promoters contains antibiotic residues, commensurate with additive doses. This situation results in antibiotic introduction to the environment.

\section{Discussion}

Detection of antibiotic residues in manure from the three most consumed animals, as well as incomplete removal in typical waste management practices, is an emerging concern given increasingly globalized food markets. This scenario is complex as increasing populations, developing countries, and urbanization demand more food resources and often involve increasingly meat-centered diets. However, for the same reasons, the efficacy of medicine is of grave importance, especially in rapidly developing countries like Brazil, China, and
India. Molton et al. [120], among others, argue that infection control, surveillance, and antimicrobial stewardship (i.e., the topic of concern for this review) are the most important tools against the spread of antibiotic resistance. The cost of developing new pharmaceuticals, including antibiotics, hinders the ability to address this crisis through discovery of novel drugs. Currently, 39 antibiotics are in development, with 12 in phase 3 trials. Due to the eventual development of resistance to these compounds, some have advocated for the development and use of antimicrobial peptides $[121,122]$ and other alternative treatments $[123,124]$.

\section{Antimicrobial Resistance}

Here, we have focused on synthesizing reports on antibiotic residues in animal manure and documenting the removal of 
antibiotics in conventional agricultural waste treatment processes. Nevertheless, increased understanding of the fate of antibiotic-resistant bacteria and antimicrobial resistance genes in such practices is also valuable. Runoff from conventional agricultural waste management (i.e., poultry litter piles, manure lagoons, etc.) has been widely implicated in the spread of antimicrobial resistance $[10,13,125,126]$. A number of previous reviews have tackled issues relating to antimicrobial resistance and animal production [127-131]. For the sake of brevity, those issues are not revisited here; however, critical knowledge gaps remain with respect to the impact of treatment processes on inactivation of resistant bacteria and destruction of antimicrobial resistance genes.

The connection between antibiotic residues and antibiotic resistance has been highlighted in popular news outlets in recent years, especially with respect to antibiotic use in animal production [132-134]. For example, many fast food producers/outlets, including Perdue, Panera, McDonald's, Tyson, and Chipotle, have vowed to eliminate or reduce antibiotic use in animal production. Regardless, antimicrobial drug sales and distribution data reported by the FDA demonstrates that antimicrobial use has consistently risen from 2009 to 2014. In fact, antimicrobial use in the USA rose from 12.6 million $\mathrm{kg}$ in 2009 to 15.4 million $\mathrm{kg}$ in 2014. Key increases were noted among lincosamides (150\% growth from 2009 to 2014), cephalosporins (57\% increase), and aminoglycosides (36\% increase). Ionophores and tetracyclines remain the most consumed classes of antimicrobials with over 4.7 and 6.6 million $\mathrm{kg}$, respectively, used in 2014 . The preponderance of antibiotic use in animal production amid widespread levels of antimicrobial resistance indicates the need for increased regulation of antibiotic use in agriculture.

\section{Regulations}

The discussion over banning the use of antimicrobials in animal feeding operations is not new. In 1969, the Swann Committee (UK) recommended a ban on subtherapeutic use in animal feed based on concerns about development of antimicrobial resistance in human pathogens [135]. Similar reports were made in the USA throughout the 1980s [24]. In 1997, the World Health Organization (WHO) published a report linking antimicrobial use in food animals to antimicrobial resistance in human pathogens [136]. WHO has released several reports since that time further documenting the spread of antimicrobial resistance and connections to antibiotic use in animal production $[25,28,65,137]$. The foreword of the 2014 WHO report, Antimicrobial Resistance: Global Report on Surveillance, indicates that a post-antibiotic era is a real possibility in the twenty-first century due to the alarming rate of development and spread of antibiotic resistance [25].

Currently, 11 countries have surveillance programs for antimicrobial resistant bacteria (i.e., Salmonella,
Campylobacter, Escherichia coli, Enterococci, and animal pathogens) in healthy/diseased animals, food, and healthy/ diseased humans [25]. Only Denmark monitors all scenarios. Eight countries, namely Denmark, Finland, France, Italy, Japan, Norway, USA, and Sweden, monitor antibioticresistant bacteria in food. Currently, widespread programs focused on the preponderance of antibiotic residues, antibioticresistant bacteria, and/or antimicrobial resistance genes in animal manure are not available. These data may provide important insight into the fate and transport of antibiotics in agriculturally intense areas. Furthermore, efforts to quantify antibiotic residues in food products may help to ensure food safety and public health.

Seventeen years after Swann's recommendation to ban subtherapeutic use of antimicrobials in animal feed, Sweden became the first country to eliminate antimicrobial use for growth promotion [138]. In other countries, regulations against the use of antimicrobials in animal feed were enacted beginning in the late 1990s. The European Union banned avoparcin, a glycopeptide, in 1997 [28]. In 1998, Denmark banned the use of virginiamycin. Shortly thereafter, a voluntary ban on all antimicrobial growth promoters was enacted in Danish poultry, swine, and cattle [28]. A number of other antimicrobials, including bacitracin (cyclopeptide), spiramycin (macrolide), tylosin (macrolide), and virginiamycin (streptogramin), were banned in the European Union in 1999. Other antimicrobials, including carbadox, avilamycin (orthosomycin), olaquindox (quinoxaline), and salinomycin (ionophores), are banned in select countries. In 2006, the European Union instituted an overall ban on the use of antibiotic growth promoters [139]; Mexico and Taiwan also have national bans on the use of antimicrobial growth promoters [140]. Although subtherapeutic use of antimicrobial growth promoters is prohibited in the European Union [141, 142], the use of these chemicals in other countries is still common. Given the increased globalization of food production and markets, international agreements limiting the use of antimicrobials in animal production may be an important step to reducing the continued development and spread of resistance. This strategy is especially true in countries where human-use antimicrobials are used in animal production.

\section{Conclusions}

The twenty-first century is a critical period in the use of antimicrobials. After $60+$ years of antibiotic use in human and veterinary medicine, many pathogens have developed resistance mechanisms. Furthermore, multidrug-resistant bacteria have been increasingly identified, generating concerns over superbugs that cannot be treated with conventional antibiotics. In this review, we have focused on describing the presence of antimicrobials in animal manure and the ability of conventional agricultural waste management systems to treat antibiotic 
residues, thereby, decreasing the selective pressure for development of resistance. Concluding thoughts, along with areas for continued research, are summarized below:

- Fluoroquinolones, sulfonamides, and tetracyclines have been widely identified in poultry litter, swine manure, and cattle manure. These detections include human-use compounds that have been labeled as "critically important" for human medicine. Increased efforts to identify metabolic products of these antibiotics will contribute to a better understanding of the total antimicrobial load in manure streams.

- Fewer detections of antimicrobials from other classes (e.g., beta-lactams, lincosamides, macrolides, and polypeptides, among others) have been reported; however, as pressure increases to reduce the use of fluoroquinolones, sulfonamides, and tetracyclines in animal feeding operations, efforts to identify residues from these other antibiotics are critical. The continued development of novel analytical methods for measurement of large suites of antibiotics in complex matrices, like manure, will facilitate continued efforts in this area.

- For many antibiotics, increased management of compost piles (i.e., turning, aeration, etc.) does not significantly affect antimicrobial degradation. High treatment efficiencies were observed regardless of management intensity. However, observed removals are believed to rely on sorption and thus antibiotics in manure may not be transformed into benign products through composting.

- Anaerobic digestion exhibited relatively high treatment efficiencies for most antimicrobials, with the exception of lincosamides, select sulfonamides, and danofloxacin. To date, most research efforts have focused on the impacts of antimicrobials on biogas production; however, efforts to optimize digesters for antibiotic degradation would facilitate improved removal of antimicrobials from agricultural waste.

- Increased management of lagoons, namely operating under aerobic conditions, resulted in higher antibiotic removal efficiencies. Regardless, the additional operational complexity and costs inhibit widespread adoption of this practice. Antibiotic stability in sediment from aerobic/ anaerobic lagoons remains an area of interest, because accumulation of antibiotics in lagoons may increase the rate of single- and multidrug resistance development.

- Available data for antibiotic degradation during composting, anaerobic digestion, and aerobic/anaerobic lagooning did not elucidate any overall trends in treatment. This finding highlights the diversity of antibiotic molecules. Optimization of agricultural waste management for priority antibiotics (identified from concentrations in manure and potential threat to human health) represents an important area for future research. Furthermore, efforts that integrate treatment of antimicrobials and resource recovery may provide the best option for incorporation into full-scale operations.

- While a number of countries contain surveillance programs for antibiotic-resistant bacteria in animals, food, and humans, concerted efforts to measure antibiotic residues in manure are equally important, especially because land application of manure represents a major avenue of antibiotic introduction to environmental systems and water supplies.

\section{Compliance with Ethical Standards}

Conflict of Interest On behalf of all authors, the corresponding author states that there is no conflict of interest.

\section{References}

1. Kresge N, Simoni RD, Hill RL. Selman Waksman: the father of antibiotics. J Biol Chem. 2004;279(48):101-2.

2. Waksman SA, Lechevalier HA. Neomycin, a new antibiotic active against streptomycin-resistant bacteria, including tuberculosis organisms. Science. 1949;109(2830):305-7.

3. Schatz A, Bugle E, Waksman SA. Streptomycin, a substance exhibiting antibiotic activity against gram-positive and gramnegative bacteria. Exp Biol Med. 1944;55(1):66-9.

4. Waksman SA, Woodruff HB. Actinomyces antibioticus, a new soil organism antagonistic to pathogenic and non-pathogenic bacteria. J Bacteriol. 1941;42(2):231-49.

5. Summons TG. Animal feed additives, 1940-1966. Agricultural History 1968, 305-313.

6. Markets and Markets. Animal antimicrobials and antibiotics market by products (tetracyclines, penicillins, sulfonamides, aminoglycosides), animals (dog, poultry, swine), mode of delivery (premixes, oral powders and solutions, injections) - global forecasts to 2018 . May, 2014.

7. USDA. USDA Economic Research Service Food Availability Documentation. Accessed at http://www.ers.usda.gov/dataproducts/food-availability-(per-capita)-data-system/foodavailability-documentation.aspx on Jan 14, 2016.

8. Nachman KE, Baron PA, Raber G, Francesconi KA, Navas-Acien A, Love DC. Roxarsone, inorganic arsenic, and other arsenic species in chicken: a U.S.-based market basket sample. Environ Health Perspect. 2013;121(7):818-24.

9. Lasky T, Sun W, Kadry A, Hoffman MK. Mean total arsenic concentrations in chicken, and estimated exposures for consumers of chicken 1989-2000. Environ Health Perspect. 2004;112(1): 18-21.

10. Tao C-W, Hsu B-M, Ji W-T, Hsu T-K, Kao P-M, Hsu C-P, et al. Evaluation of five antibiotic resistance genes in wastewater treatment systems of swine farms by real-time PCR. Sci Total Environ. 2014;496:116-21.

11. Brooks JP, Adeli A, McLaughlin MR. Microbial ecology, bacterial pathogens, and antibiotic resistant genes in swine manure wastewater as influenced by three swine management systems. Water Res. 2014;57:96-103. 
12. Cheng W, Chen H, Su C, Yan S. Abundance and persistence of antibiotic resistance genes in livestock farms: a comprehensive investigation in eastern China. Environ Int. 2013;61:1-7.

13. Furtula V, Farrell E, Diarrassouba F, Rempel H, Pritchard J, Diarra M. Veterinary pharmaceuticals and antibiotic resistance of Escherichia coli isolates in poultry litter from commercial farms and controlled feeding trials. Poult Sci. 2010;89(1):180-8.

14. Olonitola OS, Fahrenfeld N, Pruden A. Antibiotic resistance profiles among mesophilic aerobic bacteria in Nigerian chicken litter and associated antibiotic resistance genes. Poult Sci. 2015;94(5): 867-74.

15. Van den Bogaard A, Willems R, London N, Top J, Stobberingh E. Antibiotic resistance of faecal enterococci in poultry, poultry farmers and poultry slaughterers. J Antimicrob Chemother. 2002;49(3):497-505.

16. Campagnolo ER, Johnson KR, Karpati A, Rubin CS, Kolpin DW, Meyer MT, et al. Antimicrobial residues in animal waste and water resources proximal to large-scale swine and poultry feeding operations. Sci Total Environ. 2002;299(1):89-95.

17. Sun P, Barmaz D, Cabrera ML, Pavlostathis SG, Huang C-H. Detection and quantification of ionophore antibiotics in runoff, soil and poultry litter. J Chromatogr A. 2013;1312:10-7.

18. Leal RMP, Figueira RF, Tornisielo VL, Regitano JB. Occurrence and sorption of fluoroquinolones in poultry litters and soils from São Paulo State, Brazil. Sci Total Environ. 2012;432:344-9.

19. Li Y-X, Zhang X-L, Li W, Lu X-F, Liu B, Wang J. The residues and environmental risks of multiple veterinary antibiotics in animal faeces. Environ Monit Assess. 2013;185(3):2211-20.

20. Zhou L-J, Ying G-G, Liu S, Zhang R-Q, Lai H-J, Chen Z-F, et al. Excretion masses and environmental occurrence of antibiotics in typical swine and dairy cattle farms in China. Sci Total Environ. 2013;444:183-95.

21. Qiao M, Chen W, Su J, Zhang B, Zhang C. Fate of tetracyclines in swine manure of three selected swine farms in China. J Environ Sci. 2012;24(6):1047-52.

22. Pan X, Qiang Z, Ben W, Chen M. Residual veterinary antibiotics in swine manure from concentrated animal feeding operations in Shandong Province, China. Chemosphere. 2011;84(5):695-700.

23. USDA. USDA Natural Resources Conservation Service, Agricultural Waste Management Field Handbook, 2009.

24. Morton, N. S.; Institute of Medicine, Committee on Human Health Risk Assessment of Using Subtherapeutic Antibiotics in Animal Feeds; Institute of Medicine, Division of Health Promotion, Disease Prevention; US Food and Drug Administration. Human health risks with the subtherapeutic use of penicillin or tetracyclines in animal feed. National Academies, 1989.

25. WHO. Antimicrobial resistance: global report on surveillance. World Health Organization, 2014, p 256

26. Moore PR, Evenson A, Luckey TD, McCoy E, Elvehjem CA, Hart EB. Use of sulfasuxidine, streptothricin, and streptomycin in nutritional studies with the chick. J Biol Chem. 1946;165: 437-41.

27. Gaskins HR, Collier CT, Anderson DB. Antibiotics as growth promotants: mode of action. Anim Biotechnol. 2002;13(1):29-42.

28. WHO. Impacts of antimicrobial growth promoter termination in Denmark: the WHO international review panel's evaluation of the termination of the use of antimicrobial growth promoters in Denmark: Foulum, Denmark 6-9 November 2002. World Health Organization, 2003.

29. Bolan NS, Szogi AA, Chuasavathi T, Seshadri B, Rothrock MJ, Panneerselvam P. Uses and management of poultry litter. World's Poult Sci J. 2010;66(04):673-98.

30. McEwen SA, Fedorka-Cray PJ. Antimicrobial use and resistance in animals. Clin Infect Dis. 2002;34(Supplement 3):S93-S106.
31. Dewey CE, Cox BD, Straw BE, Bush EJ, Hurd HS. Associations between off-label feed additives and farm size, veterinary consultant use, and animal age. Prev Vet Med. 1997;31(1-2):133-46.

32. FDA. Summary report on antimicrobials sold or distributed for use in food-producing animals. Food and Drug Administration, Department of Health and Human Services; 2011.

33. Chee-Sanford JC, Mackie RI, Koike S, Krapac IG, Lin Y-F, Yannarell AC, et al. Fate and transport of antibiotic residues and antibiotic resistance genes following land application of manure waste. J Environ Qual. 2009;38:1086-108.

34. AHI. Survey shows decline in antibiotic use in animals. Available at http://www.ahi.org/content.asp?contentid $=694$ (verified 15 Jan 2016). Animal Health Institute, Washington, DC.

35. FDA. Phasing out certain antibiotic use in farm animals. Available at <http://www.fda.gov/ForConsumers/ConsumerUpdates/ ucm378100.htm>.

36. FDA. FDA announces pending withdrawal of approval of nitarsone. Accessed at http://www.fda.gov/AnimalVeterinary/ NewsEvents/CVMUpdates/ucm440668.htm on Jan 25, 2016.

37. Kumar KC, Gupta S, Chander Y, Singh AK. Antibiotic use in agriculture and its impact on the terrestrial environment. In Advances in agronomy, Academic Press. 2005; 87:1-54.

38. Brunton LL, Chabner B, Knollmann BC. Goodman \& Gilman's the pharmacological basis of therapeutics. New York: McGrawHill Medical; 2011. 12.

39. Zhao L, Dong YH, Wang H. Residues of veterinary antibiotics in manures from feedlot livestock in eight provinces of China. Sci Total Environ. 2010;408(5):1069-75.

40. Martínez-Carballo E, González-Barreiro C, Scharf S, Gans O. Environmental monitoring study of selected veterinary antibiotics in animal manure and soils in Austria. Environ Pollut. 2007;148(2):570-9.

41. Hamscher G, Pawelzick HT, Höper H, Nau H. Different behavior of tetracyclines and sulfonamides in sandy soils after repeated fertilization with liquid manure. Environ Toxicol Chem. 2005;24(4):861-8.

42. Haller MY, Müller SR, McArdell CS, Alder AC, Suter MJF, Quantification of veterinary antibiotics (sulfonamides and trimethoprim) in animal manure by liquid chromatography-mass spectrometry. J Chromatogr A. 2002;952(1-2):111-20.

43. Angenent LT, Mau M, George U, Zahn JA, Raskin L. Effect of the presence of the antimicrobial tylosin in swine waste on anaerobic treatment. Water Res. 2008;42(10-11):2377-84.

44. Loftin KA, Henny C, Adams CD, Surampali R, Mormile MR. Inhibition of microbial metabolism in anaerobic lagoons by selected sulfonamides, tetracyclines, lincomycin, and tylosin tartrate. Environ Toxicol Chem. 2005;24(4):782-8.

45. Wang X, Guo R, Ma B, Liang J, Liao X, Wu Y. Fate of tylosin a and its effect on anaerobic digestion using two tylosin inclusion methods. Environ Prog Sustain Energy. 2014;33(3):808-13.

46. Kuchta SL, Cessna AJ. Lincomycin and spectinomycin concentrations in liquid swine manure and their persistence during simulated manure storage. Arch Environ Contam Toxicol. 2008;57(1): $1-10$.

47. Stone JJ, Clay SA, Zhu Z, Wong KL, Porath LR, Spellman GM. Effect of antimicrobial compounds tylosin and chlortetracycline during batch anaerobic swine manure digestion. Water Res. 2009;43(18):4740-50.

48. Joy SR, Li X, Snow DD, Gilley JE, Woodbury B, Bartelt-Hunt SL. Fate of antimicrobials and antimicrobial resistance genes in simulated swine manure storage. Sci Total Environ. 2014;481: 69-74.

49. Dreher TM, Mott HV, Lupo CD, Oswald AS, Clay SA, Stone JJ. Effects of chlortetracycline amended feed on anaerobic sequencing batch reactor performance of swine manure digestion. Bioresour Technol. 2012;125:65-74. 
50. De Liguoro M, Cibin V, Capolongo F, Halling-Sørensen B, Montesissa C. Use of oxytetracycline and tylosin in intensive calf farming: evaluation of transfer to manure and soil. Chemosphere. 2003;52(1):203-12.

51. Arikan OA, Mulbry W, Rice C. Management of antibiotic residues from agricultural sources: use of composting to reduce chlortetracycline residues in beef manure from treated animals. J Hazard Mater. 2009;164(2-3):483-9.

52. Hamscher G, Abu-Quare A, Sczesny S, Höper H, Nau H. In Determination of tetracyclines and tylosin in soil and water samples from agricultural areas in lower Saxony. 2000; 8-10.

53. Arikan OA, Sikora LJ, Mulbry W, Khan SU, Foster GD. Composting rapidly reduces levels of extractable oxytetracycline in manure from therapeutically treated beef calves. Bioresour Technol. 2007;98(1):169-76.

54. Arikan OA, Sikora LJ, Mulbry W, Khan SU, Rice C, Foster GD. The fate and effect of oxytetracycline during the anaerobic digestion of manure from therapeutically treated calves. Process Biochem. 2006;41(7):1637-43.

55. Ince B, Coban H, Turker G, Ertekin E, Ince O. Effect of oxytetracycline on biogas production and active microbial populations during batch anaerobic digestion of cow manure. Bioprocess Biosyst Eng. 2013;36(5):541-6.

56. Bao Y, Zhou Q, Guan L, Wang Y. Depletion of chlortetracycline during composting of aged and spiked manures. Waste Manag. 2009;29(4):1416-23.

57. Grote M, Vockel A, Schwarze D, Mehlich A, Freitag M. Fate of antibiotics in food chain and environment originating from pig fattening (part 1). Fresenius Environ Bull. 2004;13(11):1216-24.

58. Dahshan H, Abd-Elall AMM, Megahed AM, Abd-El-Kader MA, Nabawy EE. Veterinary antibiotic resistance, residues, and ecological risks in environmental samples obtained from poultry farms, Egypt. Environ Monit Assess. 2015;187(2):1-10.

59. Arikan OA, Rice C, Codling E. Occurrence of antibiotics and hormones in a major agricultural watershed. Desalination. 2008;226(1-3):121-33.

60. Morales-Gutierrez FJ, Hermo MP, Barbosa J, Barron D. Highresolution mass spectrometry applied to the identification of transformation products of quinolones from stability studies and new metabolites of enrofloxacin in chicken muscle tissues. J Pharm Biomed Anal. 2014;92:165-76.

61. Slana M, Pahor V, Cvitkovic Maricic L, Sollner-Dolenc M. Excretion pattern of enrofloxacin after oral treatment of chicken broilers. J Vet Pharmacol Ther. 2014;37(6):611-4.

62. Pourcher AM, Jadas-Hécart A, Cotinet P, Dabert P, Ziebal C, Le Roux S, et al. Effect of land application of manure from enrofloxacin-treated chickens on ciprofloxacin resistance of Enterobacteriaceae in soil. Sci Total Environ. 2014;482-483: 269-75.

63. Janusch F, Scherz G, Mohring SA, Stahl J, Hamscher G. Comparison of different solid-phase extraction materials for the determination of fluoroquinolones in chicken plasma by LC-MS/ MS. J Chromatogr B: Anal Technol Biomed Life Sci. 2014;951952:149-56.

64. Ola S. Resistance to trimethoprim and sulfonamides. Vet Res. 2001;32(3-4):261-73.

65. WHO. Critically important antibacterial agents for human medicine for risk management strategies of non-human use: report of a WHO working group consultation. Canberra: World Health Organization; 2005.

66. Clarke L, Fodey TL, Crooks SRH, Moloney M, O’Mahony J, Delahaut P, et al. A review of coccidiostats and the analysis of their residues in meat and other food. Meat Sci. 2014;97(3): 358-74.

67. Mangalgiri KP, Adak A, Blaney L. Organoarsenicals in poultry litter: detection, fate, and toxicity. Environ Int. 2015;75:68-80.
68. Cortinas I, Field JA, Kopplin M, Garbarino JR, Gandolfi AJ, Sierra-Alvarez R. Anaerobic biotransformation of roxarsone and related N-substituted phenylarsonic acids. Environ Sci Technol. 2006;40(9):2951-7.

69. Garbarino JR, Bednar AJ, Rutherford DW, Beyer RS, Wershaw RL. Environmental fate of roxarsone in poultry litter. I. Degradation of roxarsone during composting. Environ Sci Technol. 2003;37(8):1509-14.

70. Adak A, Mangalgiri, Lee J, Blaney L. UV irradiation and UV$\mathrm{H} 2 \mathrm{O} 2$ advanced oxidation of the roxarsone and nitarsone organoarsenicals. Water Res. 2015;70:74-85.

71. Fu Q-L, He J-Z, Gong H, Blaney L, Zhou D-M. Extraction and speciation analysis of roxarsone and its metabolites from soils with different physicochemical properties. J Soils Sediments. 2016; $1-12$.

72. Chen W-R, Huang C-H. Surface adsorption of organoarsenic roxarsone and arsanilic acid on iron and aluminum oxides. J Hazard Mater. 2012;227-228:378-85.

73. USDA. Livestock and poultry: world markets and trade. 2015.

74. Stone JJ, Clay SA, Spellman GM. Tylosin and chlortetracycline effects during swine manure digestion: influence of sodium azide. Bioresour Technol. 2010;101(24):9515-20.

75. Joy SR, Bartelt-Hunt SL, Snow DD, Gilley JE, Woodbury BL, Parker DB, et al. Fate and transport of antimicrobials and antimicrobial resistance genes in soil and runoff following land application of swine manure slurry. Environ Sci Technol. 2013;47(21):12081-8.

76. Kuchta SL, Cessna AJ. Lincomycin and spectinomycin concentrations in liquid swine manure and their persistence during simulated manure storage. Arch Environ Contam Toxicol. 2009;57(1): $1-10$.

77. Arikan O, Mulbry W, Ingram D, Millner P. Minimally managed composting of beef manure at the pilot scale: effect of manure pile construction on pile temperature profiles and on the fate of oxytetracycline and chlortetracycline. Bioresour Technol. 2009;100(19):4447-53.

78. Arikan OA. Degradation and metabolization of chlortetracycline during the anaerobic digestion of manure from medicated calves. $\mathrm{J}$ Hazard Mater. 2008;158(2-3):485-90.

79. Pruden A, Arabi M, Storteboom HN. Correlation between upstream human activities and riverine antibiotic resistance genes. Environ Sci Technol. 2012;46(21):11541-9.

80. Tallman P, Ruscigno M. The restore-our-planet diet: food choices, our environment, and our health. CreateSpace Independent Publishing Platform. 2015.

81. WHO. Critically important antimicrobials for human medicine. World Health Organization: 2012.

82. Melse RW, Verdoes N. Evaluation of four farm-scale systems for the treatment of liquid pig manure. Biosyst Eng. 2005;92(1): $47-57$.

83. Kunz A, Miele M, Steinmetz RLR. Advanced swine manure treatment and utilization in Brazil. Bioresour Technol. 2009;100(22): 5485-9.

84. Flotats X, Bonmatí A, Fernández B, Magrí A. Manure treatment technologies: on-farm versus centralized strategies. NE Spain as case study. Bioresour Technol. 2009;100(22):5519-26.

85. Hu Z, Liu Y, Chen G, Gui X, Chen T, Zhan X. Characterization of organic matter degradation during composting of manure-straw mixtures spiked with tetracyclines. Bioresour Technol. 2011;102(15):7329-34.

86. Sharma R, Larney FJ, Chen J, Yanke LJ, Morrison M, Topp E, et al. Selected antimicrobial resistance during composting of manure from cattle administered sub-therapeutic antimicrobials. J Environ Qual. 2009;38(2).

87. Dolliver H, Gupta S, Noll S. Antibiotic degradation during manure composting. J Environ Qual. 2008;37(3):1245-53. 
88. Ramaswamy J, Prasher SO, Patel RM, Hussain SA, Barrington SF. The effect of composting on the degradation of a veterinary pharmaceutical. Bioresour Technol. 2010;101(7):2294-9.

89. Selvam A, Zhao Z, Wong JWC. Composting of swine manure spiked with sulfadiazine, chlortetracycline and ciprofloxacin. Bioresour Technol. 2012;126:412-7.

90. Kim KR, Owens G, Ok YS, Park WK, Lee DB, Kwon SI. Decline in extractable antibiotics in manure-based composts during composting. Waste Manag. 2012;32(1):110-6.

91. Storteboom HN, Kim S-C, Doesken KC, Carlson KH, Davis JG, Pruden A. Response of antibiotics and resistance genes to highintensity and low-intensity manure management. J Environ Qual. 2007;36(6):1695-703

92. Li L-L, Huang L-D, Chung R-S, Fok K-H, Zhang Y-S. Sorption and dissipation of tetracyclines in soils and compost. Pedosphere. 2010;20(6):807-16.

93. Macias-Corral M, Samani Z, Hanson A, Smith G, Funk P, Yu H, et al. Anaerobic digestion of municipal solid waste and agricultural waste and the effect of co-digestion with dairy cow manure. Bioresour Technol. 2008;99(17):8288-93.

94. Ward AJ, Hobbs PJ, Holliman PJ, Jones DL. Optimisation of the anaerobic digestion of agricultural resources. Bioresour Technol. 2008;99(17):7928-40.

95. Mitchell SM, Ullman JL, Teel AL, Watts RJ, Frear C. The effects of the antibiotics ampicillin, florfenicol, sulfamethazine, and tylosin on biogas production and their degradation efficiency during anaerobic digestion. Bioresour Technol. 2013;149:244-52.

96. Sara P, Giuliana DI, Michele P, Maurizio C, Luca C, Fabrizio A. Effect of veterinary antibiotics on biogas and bio-methane production. Int Biodeterior Biodegradation. 2013;85:205-9.

97. Mohring SAI, Strzysch I, Fernandes MR, Kiffmeyer TK, Tuerk J, Hamscher G. Degradation and elimination of various sulfonamides during anaerobic fermentation: a promising step on the way to sustainable pharmacy? Environ Sci Technol. 2009;43(7): 2569-74.

98. Shi JC, Liao XD, Wu YB, Liang JB. Effect of antibiotics on methane arising from anaerobic digestion of pig manure. Anim Feed Sci Technol. 2011;166-167:457-63.

99. Álvarez JA, Otero L, Lema JM, Omil F. The effect and fate of antibiotics during the anaerobic digestion of pig manure. Bioresour Technol. 2010;101(22):8581-6.

100. Ndegwa P, Hamilton D, Lalman J, Cumba H. Optimization of anaerobic sequencing batch reactors treating dilute swine slurries. Trans Am Soc Agric Eng. 2005;48(4):1575-83.

101. Shimada T, Zilles JL, Morgenroth E, Raskin L. Inhibitory effects of the macrolide antimicrobial tylosin on anaerobic treatment. Biotechnol Bioengineering. 2008;101(1):73-82.

102. Massé DI, Lu D, Masse L, Droste RL. Effect of antibiotics on psychrophilic anaerobic digestion of swine manure slurry in sequencing batch reactors. Bioresour Technol. 2000;75(3):205-11.

103. Bauer A, Lizasoain J, Nettmann E, Bergmann I, Mundt K, Klocke $\mathrm{M}$, et al. Effects of the antibiotics chlortetracycline and enrofloxacin on the anaerobic digestion in continuous experiments. Bioenergy Res. 2014;7(4):1244-52.

104. Stone JJ, Oswald AS, Lupo CD, Clay SA, Mott HV. Impact of chlortetracycline on sequencing batch reactor performance for swine manure treatment. Bioresour Technol. 2011;102(17):7807-14.

105. Gamal-El-Din, H. Biogas production from antibioticcontaminated cow manure. In Biogas technology, transfer and diffusion, Springer: 1986; pp 480-487.

106. Varel VH, Hashimoto AG. Methane production by fermentor cultures acclimated to waste from cattle fed monensin, lasalocid, salinomycin, or avoparcin. Appl Environ Microbiol. 1982;44(6): 1415-20.
107. Lallai A, Mura G, Onnis N. The effects of certain antibiotics on biogas production in the anaerobic digestion of pig waste slurry. Bioresour Technol. 2002;82(2):205-8.

108. Varel VH, Hashimoto AG. Effect of dietary monensin or chlortetracycline on methane production from cattle waste. Appl Environ Microbiol. 1981;41(1):29-34.

109. Poels J, Van Assche P, Verstraete W. Effects of disinfectants and antibiotics on the anaerobic digestion of piggery waste. Agric Wastes. 1984;9(4):239-47.

110. García-Sánchez L, Garzón-Zúñiga MA, Buelna G, EstradaArriaga EB. Tylosin effect on methanogenesis in an anaerobic biomass from swine wastewater treatment. Water Sci Technol. 2015;73(2):445-52.

111. Ke X, Wang C-Y, Li R-D, Zhang Y. Effects of oxytetracycline on methane production and the microbial communities during anaerobic digestion of cow manure. J Int Agric. 2014;13(6):1373-81.

112. Sanz LJ, Rodríguez N, Amils R. The action of antibiotics on the anaerobic digestion process. Appl Microbiol Biotechnol. 1996;46(5):587-92.

113. Beneragama N, Lateef SA, Iwasaki M, Yamashiro T, Umetsu K. The combined effect of cefazolin and oxytertracycline on biogas production from thermophilic anaerobic digestion of dairy manure. Bioresour Technol. 2013;133:23-30.

114. Ince B, Coban H, Turker G, Ertekin E, Ince O. Effect of oxytetracycline on biogas production and active microbial populations during batch anaerobic digestion of cow manure. Bioprocess Biosyst Eng. 2012;36(5):541-6.

115. Jindal A, Kocherginskaya S, Mehboob A, Robert M, Mackie RI, Raskin L, et al. Antimicrobial use and resistance in swine waste treatment systems. Appl Environ Microbiol. 2006;72(12):7813-20.

116. Pei R, Cha J, Carlson KH, Pruden A. Response of antibiotic resistance genes (ARG) to biological treatment in dairy lagoon water. Environ Sci Technol. 2007;41(14):5108-13.

117. Kühne M, Ihnen D, Möller G, Agthe O. Stability of tetracycline in water and liquid manure. J Vet Med Ser A. 2000;47(6):379-84.

118. McKinney CW, Loftin KA, Meyer MT, Davis JG, Pruden A. Tet and Sul antibiotic resistance genes in livestock lagoons of various operation type, configuration, and antibiotic occurrence. Environ Sci Technol. 2010;44(16):6102-9.

119. Peak N, Knapp CW, Yang RK, Hanfelt MM, Smith MS, Aga DS, et al. Abundance of six tetracycline resistance genes in wastewater lagoons at cattle feedlots with different antibiotic use strategies. Environ Microbiol. 2007;9(1):143-51.

120. Molton JS, Tambyah PA, Ang BSP, Ling ML, Fisher DA. The global spread of healthcare-associated multidrug-resistant bacteria: a perspective from Asia. Clin Infect Dis. 2013;56(9):1310-8.

121. Menousek J, Mishra B, Hanke ML, Heim CE, Kielian T, Wang G. Database screening and in vivo efficacy of antimicrobial peptides against methicillin-resistant Staphylococcus aureus USA300. Int J Antimicrob Agents. 2012;39(5):402-6.

122. Hassan M, Kjos M, Nes IF, Diep DB, Lotfipour F. Natural antimicrobial peptides from bacteria: characteristics and potential applications to fight against antibiotic resistance. J Appl Microbiol. 2012;113(4):723-36.

123. Stanley VG, Gray C, Daley M, Krueger WF, Sefton AE. An alternative to antibiotic-based drugs in feed for enhancing performance of broilers grown on Eimeria spp.-infected litter. Poult Sci. 2004;83(1):39-44.

124. Ferket PR, Lyons TP, Jacques KA. In alternatives to antibiotics in poultry production: responses, practical experience and recommendations. UK: Alltech; 2004. p. 57-67.

125. Liu L, Liu Y-H, Wang Z, Liu C-X, Huang X, Zhu G-F. Behavior of tetracycline and sulfamethazine with corresponding resistance genes from swine wastewater in pilot-scale constructed wetlands. J Hazard Mater. 2014;278:304-10. 
126. Kyselková M, Jirout J, Chroňáková A, Vrchotová N, Bradley R, Schmitt H, et al. Cow excrements enhance the occurrence of tetracycline resistance genes in soil regardless of their oxytetracycline content. Chemosphere. 2013;93(10):2413-8.

127. Silbergeld EK, Graham J, Price LB. Industrial food animal production, antimicrobial resistance, and human health. Annual Review of Public Health. 2008;29(1):151-69.

128. Khachatourians GG. Agricultural use of antibiotics and the evolution and transfer of antibiotic-resistant bacteria. Can Med Assoc J. 1998;159(9):1129-36.

129. Allen HK, Donato J, Wang HH, Cloud-Hansen KA, Davies J, Handelsman J. Call of the wild: antibiotic resistance genes in natural environments. Nat Rev Microbiol. 2010;8(4):251-9.

130. Hur J, Jawale C, Lee JH. Antimicrobial resistance of salmonella isolated from food animals: a review. Food Res Int. 2012;45(2): 819-30.

131. Berendonk TU, Manaia CM, Merlin C, Fatta-Kassinos D, Cytryn E, Walsh F, et al. Tackling antibiotic resistance: the environmental framework. Nat Rev Microbiol. 2015;13(5):310-7.

132. Peeples L. Can we wean our future food off antibiotics. The Huffington Post June 30, 2015.

133. Koba M. Antibiotics in meat: a public health controversy that isn't going away. Fortune June 3, 2015.

134. BBC. McDonald's to cut use of antibiotics in chicken. BBC News, Business March 5, 2015.
135. Swann MM. Joint Committee on the Use of Antibiotics in Animal Husbandry and Veterinary Medicine: report presented to Parliament by the Secretary of State for Social Services. 1969. HM Stationery Office.

136. WHO. The medical impact of the use of antimicrobials in food animals: report of a WHO meeting. Berlin: World Health Organization; 1997.

137. WHO. WHO global strategy for containment of antimicrobial resistance. World Health Organization, 2001.

138. Aarestrup FM. Effects of termination of AGP use on antimicrobial resistance in food animals. Working papers for the WHO international review panels evaluation, document WHO/CDS/CPE/ZFK/2003.1 a. Geneva: World Health Organization; 2003. p. 6-11.

139. GAO. Antibiotic resistance: agencies have made limited progress Addressing antibiotic use in animals. GAO-11-801: Published: Sep 7, 2011.

140. Maron DF, Smith TJ, Nachman KE. Restrictions on antimicrobial use in food animal production: an international regulatory and economic survey. Glob Health. 2013;9:48.

141. Commission of the European Communities. Council Reg 2788/98. Official Journal of the Euro Communities Legislation L347, 32. 1998.

142. Commission of the European Communities. Council Reg 2821/98. Official Journal of the Euro Communities Legislation L351, 4. 1998. 